\title{
Stratigraphy and chronology of a 15 ka sequence of multi-sourced silicic tephras in a montane peat bog, eastern North Island, New Zealand
}

\author{
DAVID J. LOWE \\ Department of Earth Sciences \\ University of Waikato \\ Private Bag 3105 \\ Hamilton, New Zealand \\ email: d.lowe@waikato.ac.nz
}

\section{REWI M. NEWNHAM}

Department of Geographical Sciences

University of Plymouth

Plymouth, Devon PL4 8AA

England, United Kingdom

email: r.newnham@plymouth.ac.uk

\section{CHRIS M. WARD \\ Department of Conservation \\ P.O. Box 668 \\ Gisborne, New Zealand \\ email: cward@doc.govt.nz}

\begin{abstract}
We document the stratigraphy, composition, and shronology of a succession of 16 distal, silicic tephra layers interbedded with lateglacial and Holocene peats and muds up to c. 15000 radiocarbon years (c. 18000 calendar years) old at a montane site (Kaipo Bog) in eastern North Island, New Zealand. Aged from $665 \pm 15$ to $14700 \pm 95{ }^{14} \mathrm{C}$ yr $\mathrm{BP}$, the tephras are derived from six volcanic centres in North Island, three of which are rhyolitic (Okataina, Taupo, Maroa), one peralkaline (Tuhua), and two andesitic (Tongariro, Egmont). Correlations are based on multiple criteria: field properties and stratigraphic interrelationships, ferromagnesian silicate mineral assemblages, glass-shard major element composition (from electron microprobe analysis), and radiocarbon dating. We extend the known distribution of tephras in eastern North Island and provide compositional data that add to their potential usefulness as isochronous markers. The chronostratigraphic framework established for the Kaipo sequence, based on both site-specific and independently derived tephra-based radiocarbon ages, provides the basis for fine-resolution paleoenvironmental studies at a climatically sensitive terrestrial site from the mid latitudes of the Southern Hemisphere. Tephras identified as especially useful paleoenvironmental markers include Rerewhakaaitu and Waiohau (lateglacial), Konini (lateglacial-early Holocene), Tuhua (middle Holocene), and Taupo and Kaharoa (late Holocene).
\end{abstract}

G99022

Received 4 May 1999; accepted 22 July 1999
Keywords tephra; tephrostratigraphy; tephrochronology; glass analysis; peat; radiocarbon dates; volcanism; late Quaternary; lateglacial; Holocene; Kaipo Bog; Te Urewera National Park; New Zealand

\section{INTRODUCTION}

The transition from the last cold stage to the present interglacial, the marine oxygen isotope stage $2 / 1$ boundary, or "lateglacial", has become one of the most intensively studied intervals of the Quaternary Period. This is because lateglacial records of inferred environmental change potentially may be examined with finer temporal resolution, and dated more precisely, than in earlier parts of the Quaternary, thus providing a means for understanding how Earth and atmospheric processes interact during such coldto-warm climatic transitions (Lowe \& Walker 1997; Björck et al. 1998). Similarly, the nature and timing of environmental changes in the present interglacial (Holocene) have attracted growing attention because recent studies of earlier interglacials show marked and rapid paleoclimatic fluctuations in these periods (e.g., Dansgaard et al. 1993; Seidenkrantz et al. 1995), implying that the Holocene may also be less stable climatically than previously assumed (e.g., Bond et al. 1997; Lowe et al. 1997). It is now recognised that to make further advances in detecting and understanding such short-term paleoclimatic changes for the lateglacial and Holocene periods requires the availability of proxy records with certain minimal features: sites and the records they yield must be sensitive to climatic change, they must be capable of being sampled at an appropriate high-resolution scale, and they must be chronologically well constrained using radiometric or incremental dating methods, ideally also containing age-equivalent stratigraphic markers, such as tephra layers, to test the veracity of site-specific radiometric dates and to facilitate correlation on a regional to global scale.

We have identified such a site in New Zealand that meets all these criteria. The site, at Kaipo Bog, near Lake Waikaremoana, eastern North Island (Fig. 1), comprises a c. 15000 radiocarbon $\left({ }^{14} \mathrm{C}\right)$ year long sequence of peat and mud deposits interbedded with 16 macroscopic, silicic tephra layers derived from 6 separate volcanic centres. Located at a climatically sensitive montane-subalpine environment (Newnham \& Lowe in press), the site has the potential to provide a fine-resolution record of paleoclimatic changes for the lateglacial-Holocene at a middle latitudinal, maritime location in the Southern Hemisphere, and therefore to contribute to the attainment of a gobal view of the character and timing of the last glacial-interglacial transition, including the critical "Younger Dryas" cooling interval (Greenland Stadial-1 of Björck et al. 1998) (e.g., Denton \& Hendy 1994; McGlone 1995; Taylor et al. 1997), and additionally of Holocene climatic variability. In this paper, 


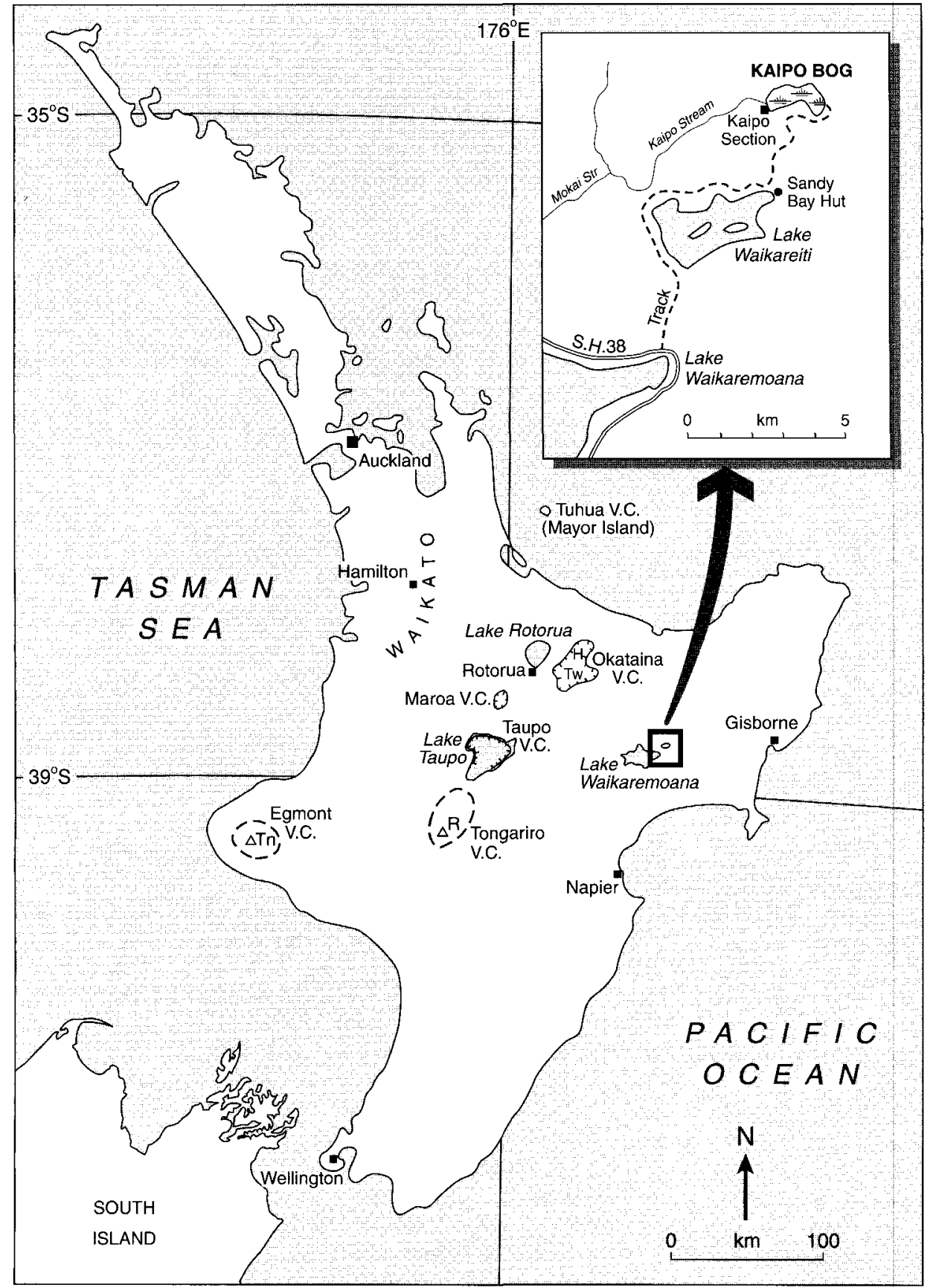

Fig. 1 Location of Kaipo Bog, North Island, New Zealand, and source volcanic centres (V.C.) of the tephras identified at Kaipo (after Froggatt \& Lowe 1990). H, Haroharo volcano; Tw, Mt Tarawera volcano; R, Mt Ruapehı volcano; Tn, Mt Taranaki/Mt Egmont volcano; S.H., Statio Highway. our primary aim is to document the tephrostratigraphy and adjunct chronology, based on radiocarbon dating, of the Kaipo Bog site to provide the chronostratigraphic framework essential for detailed paleoenvironmental studies. These studies, currently in progress, include analyses of pollen, stable carbon isotopes, and testate amoebae, and will be reported elsewhere (e.g., Newnham \& Lowe in prep.). Such studies will also permit assessment of the potential environmental impacts of tephra fall at a site well beyond the proximal hazard zone of New Zealand's active volcanic centres (e.g., see Wilmshurst \& McGlone 1996; Giles et al. 1999).

In addition to providing a tephrochronological framework, our study extends the known geographic distribution of tephras in eastern North Island, which is important for modelling the magnitude and style of tephra-generating eruptions, and for broader volcanic systems' interpretations (e.g., Wilson 1993; Houghton et al. 1995; Nairn et al. 1998; Lowe \& Newnham 1999; Shane in press). We also report new major element analyses, obtained by electron microprobe, on glass from the tephras, together with mineralogical analyses, which thereby add to their potential usefulness as isochronous stratigraphic markers. The study builds on earlier stratigraphic work at Kaipo Bog by Lowe \& Hogg (1986).

\section{KAIPO BOG AND ENVIRONS}

Kaipo Bog is a 73 ha peat bog lying at an altitude of $980 \mathrm{~m}$ above sea level to the north of Lake Waikareiti in Te Urewera 
National Park, Huiarau Range, North Island, at $38^{\circ} 40^{\prime} \mathrm{S}$ and $177^{\circ} 10^{\prime} \mathrm{E}$ (Fig. 1). It has formed within an infilled basin at the trailing edge of a $53 \mathrm{~km}^{2}$ area of landslide debris, the result of a massive landsliding event from the north (Ward 1995). Sediment derived from the surrounding debris and bedrock slopes, which are composed of sandstone and soft, blue-grey siltstone or mudstone (Moore 1979), appears to have substantially infilled the basin before peat bog development began. Except on steep or unstable slopes, generally shallow $(\mathrm{sc} .0 .6 \mathrm{~m})$ tephra-fall deposits mantle the sedimentary rocks in the area (Rijske 1979).

The bog is the largest of a group of natural enclosed clearings in the area that form small peaty wetlands and lakelets within montane-subalpine beech forest (mainly Nothofagus menziesi and N. fusca) and shrubland (New Zealand Forest Service 1969; McKelvey 1973; Newnham et al. 1998a). It is essentially an ombrogenous shrub bog dominated by rushes (mainly Empodisma minus) and ferns (Gleichenia dicarpa), with occasional Sphagnum spp., which form low hummocks amidst numerous small, permanent pools (Rogers 1984; Lowe \& Hogg 1986). Modern pollen spectra at Kaipo Bog reflect local vegetation sources but also include pollen derived from lowland-montane mixed podocarp-angiosperm-beech forest at lower altitudes as well as from grassland-shrubland communities at or above the present treeline near $1370 \mathrm{~m}$ elevation. Because the altitudinal zonation of vegetation in these uplands is controlled largely by temperature (McKelvey 1973), a pollen record from Kaipo Bog would therefore serve as an indicator of past temperature change in the region (Newnham \& Lowe in press).

A small stream and its tributaries draining the western end of Kaipo Bog have incised the bog surface to expose a series of vertical sections comprising peats and inorganic muds with interbedded tephra layers. The stratigraphy and chronology of one of these sections was studied by Lowe $\&$ Hogg (1986). Subsequent fieldwork has revealed a further three adjacent sections extending stratigraphically below that studied by Lowe \& Hogg (1986), and containing tephra beds additional to those recognised earlier. The full sequence is difficult to see in any one section because of differing watertable levels and because fallen trees and other debris covered with forest undergrowth restrict access. However, the physical characteristics of the tephra layers and other lithological features, together with stratigraphic relationships, allow the three closely spaced sections (they are only c. 5-10 $\mathrm{m}$ apart) to be readily linked to one another. This has enabled us to construct a composite stratigraphic column c. $4.4 \mathrm{~m}$ high extending from the modern peat surface to c. $15000{ }^{14} \mathrm{C}$ yr BP at the base (Fig. 2). The sequence is centred on grid reference sheet W18/739717 (based on the $1000 \mathrm{~m}$ grid of the NZMS $2601: 50000$ topographical map series).

\section{STRATIGRAPHY AND CORRELATION OF TEPHRAS}

The Kaipo sequence, from top to bottom, comprises an upper unit of black peat (0-2.75 $\mathrm{m}$ depth) grading into a unit of brown neat $(2.75-2.95 \mathrm{~m})$, a pale brownish-grey mud unit containing organic "stringers" and two peaty layers up to $100 \mathrm{~mm}$ thick (2.95-3.5 m), and a lower unit of black peat $(3.5-4.25 \mathrm{~m})$ that grades to a basal unit of olive-blue sandy mud containing very thin organic bands $(4.25-4.42 \mathrm{~m})$ (Fig. 2). Interbedded with these sediments are the 16 macroscopic tephra layers. These range from c. 10 to $280 \mathrm{~mm}$ in thickness, although thicknesses may vary laterally (Fig. 2). They are predominantly of ash grade but some are dominated by fine lapilli, and some are distinctively bedded (Table 1). The Waiohau Tephra comprises a layer c. $220 \mathrm{~mm}$ thick overlain in places by a reworked, but compositionally identical, layer c. $200 \mathrm{~mm}$ thick (see analyses $6 a-6 c$ in Table 2 , below). The total thickness of the tephras is c. $1.6 \mathrm{~m}$. The tephras newly identified here since the work of Lowe \& Hogg (1986) are the Tuhua, Mamaku, Konini, Waiohau, Puketarata, and Rerewhakaaitu Tephras. However, we did not find Mapara Tephra (equivalent to Unit-X of Wilson 1993) reported by Lowe \& Hogg (1986): it may have been misidentified in the original study or it has been eroded and is missing from the new site.

Correlation of the tephra layers is based on multiple criteria including field appearance (physical properties) and stratigraphic position, analysis of ferromagnesian silicate mineral assemblages by petrological microscope, and analysis of glass-shard major element compositions by electron microprobe (Tables 1,2). Identifications were supported by radiocarbon dating (see Chronology section below). Most of the glass compositional analyses derived from electron microprobe (Table 2) were calculated using a procedure different from that employed before 1995 at the Analytical Facility, Victoria University of Wellington (Manning 1995). The result is that, in general, silica totals tend to be slightly lower (by c. $0.5-1.0 \mathrm{wt} \%$ ) than those obtained under the previous method, and other major elements except $\mathrm{K}_{2} \mathrm{O}$ tend to be commensurately slightly greater (especially $\mathrm{Na}_{2} \mathrm{O}, \mathrm{TiO}_{2}$ ). Consequently, comparisons between glass analyses made on tephras before and after 1995 need to be judged in this light.

Most of the tephras at Kaipo Bog are derived from the rhyolitic volcanic centres of Okataina (six tephras), Taupo (six tephras), and Maroa (one tephra); one tephra is derived from the peralkaline Tuhua (Mayor Island) centre, and one is derived from each of the andesitic Tongariro and Egmont centres (Fig. 1; Froggatt \& Lowe 1990). There are relatively few systematic microprobe-derived major element glass analyses available for andesitic tephras (in contrast to rhyolitic tephras, e.g., see Stokes et al. 1992), and such analyses tend to show relatively wide variations (Lowe 1988a, b; Stokes \& Lowe 1988; Froggatt \& Rogers 1990; Eden \& Froggatt 1996; Donoghue et al. 1999). Some of this variation relates to magma mingling or fractionation (e.g., Donoghue et al. 1995a, 1999; Nakagawa et al. 1998; Price et al. 1999); some may relate to the effects of plagioclase microlites on the electron microprobe analyses (Lowe 1988b; Shane in press). Thus, the correlations for andesitic tephras are provisional. Criteria for specific correlations with named eruptives are summarised below.

\section{Okataina-derived tephras}

These are named here using the nomenclature of Froggatt \& Lowe (1990), and consist of the Kaharoa, Whakatane, Mamaku, Rotoma, Waiohau, and Rerewhakaaitu Tephras. They are dominated mineralogically by either biotite (Kaharoa, Rerewhakaaitu) or cummingtonite (Whakatane, Rotoma), or they comprise assemblages of hornblende plus 

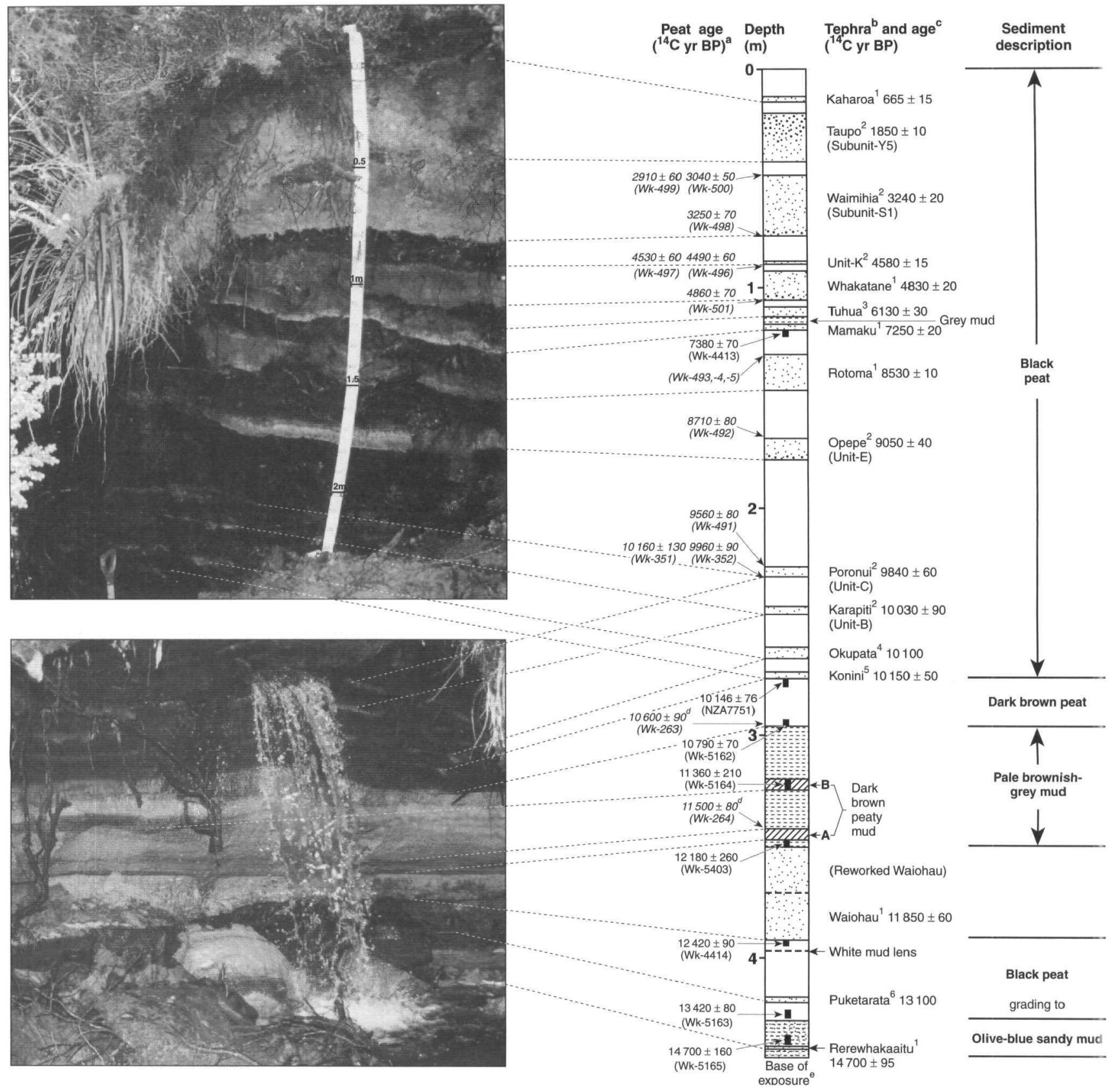

Fig. 2 Tephrostratigraphy and chronology of the Kaipo Bog sequence. ${ }^{a}$ Ages in italics are from Lowe \& Hogg (1986), others this study (Table 3); b named tephra units derived from Okataina (1), Taupo (2), Tuhua (3), Tongariro (4), Egmont (5), or Maroa (6) Volcanic Centres (Fig. 1); cages of tephras \pm 1 SD (see text and Table 1); dsampling juxtapositions of these ages (from Lowe \& Hogg 1986) are approximate; ${ }^{e}$ the base of the section is not necessarily the base of the post-landslide basin-infilling deposits. N.B. Waimihia and Unit-K ages should read $3230 \pm 20$ and $4510 \pm 20{ }^{14} \mathrm{C}$ yr BP. respectively.

hypersthene \pm augite (Waiohau, Mamaku), all of which are characterisitic for these eruptives (Lowe 1988a, b; Froggatt \& Lowe 1990). Glass shard major element compositions (anal. 1-7, Table 2), all rhyolitic*, are consistent with those for Okataina-sourced eruptives and with individual (named) tephra formations (Green \& Lowe 1985; Lowe 1986, 1988a, b; Stokes \& Lowe 1988; Froggatt \& Rogers 1990; Pillans \& Wright 1992; Stokes et al. 1992; Eden \& Froggatt 1996; Lowe et al. 1998). Ranges for selected oxides (mean values)

*Classifications of glass are based on the IUGS total alkali-silica diagram of Le Bas et al. (1986). are $\mathrm{SiO}_{2} 77.4-78.1 \%, \mathrm{TiO}_{2} 0.1-0.2 \%, \mathrm{FeO}_{\text {total }} 0.8-1.1 \%$, $\mathrm{MgO} 0.1-0.2 \%$, and $\mathrm{CaO} 0.5-1.0 \%\left(\mathrm{TiO}_{2}\right.$ is notably high, $0.22 \%$, in Waiohau Tephra).

\section{Taupo-derived tephras}

These are named according to the terminology both of Froggatt \& Lowe (1990) and Wilson (1993). They comprise Taupo (Subunit-Y5 of Wilson 1993), Waimihia (SubunitS1), Unit-K (previously called a "Hinemaiaia" eruptive: Lowe 1986; Lowe \& Hogg 1986), Opepe (Unit-E), Poronui (Unit-C), and Karapiti (Unit-B) Tephras. All are dominated by hypersthene with minor augite \pm hornblende (Table 1 ), 
Table 1 Stratigraphy and selected characteristics of tephra deposits at Kaipo Bog.

\begin{tabular}{|c|c|c|c|c|c|}
\hline $\begin{array}{l}\text { Tephra name } \\
(\text { symbol })\end{array}$ & Source $^{\mathrm{a}}$ & $\begin{array}{c}\text { Age } \\
\left({ }^{14} \mathrm{C} \text { yr BP }\right)^{\mathrm{b}}\end{array}$ & $\begin{array}{l}\text { Thickness } \\
(\mathrm{mm})\end{array}$ & General description $^{c}$ & $\begin{array}{l}\text { Ferromagnesian } \\
\text { mineralogyd }\end{array}$ \\
\hline Kaharoa $(K a)$ & $\mathrm{OK}-\mathrm{Tw}$ & $\begin{array}{l}665 \pm 15 \\
(n=14)\end{array}$ & 20 & $\begin{array}{l}\text { White fine ash with sparse hard, fine lapilli; } \\
\text { "sugary" appearance in peat where disseminated }\end{array}$ & Bio $\geq$ Hyp $>$ Hbe, Aug \\
\hline $\begin{array}{l}\text { Taupo }(T p) \\
{[\text { Subunit-YS } 5]^{\mathrm{e}}}\end{array}$ & $\mathrm{TP}$ & $\begin{array}{c}1850 \pm 10 \\
(n=41)\end{array}$ & 220 & Orange fine lapilli over yellowish coarse ash & Hyp $\gg>$ Aug \\
\hline $\begin{array}{l}\text { Waimihia }(\mathrm{Wm}) \\
{[\text { Subunit-Sl] }}\end{array}$ & $\mathrm{TP}$ & $\begin{array}{c}3230 \pm 20 \\
(n=17)\end{array}$ & 280 & $\begin{array}{l}\text { Greyish-white medium to fine ash (top } 50 \mathrm{~mm} \text { ) } \\
\text { over "blotchy" grey medium ash over yellowish- } \\
\text { reddish fine lapilli and coarse ash at base }\end{array}$ & Hyp $\gg$ Aug \\
\hline Unit-K $(-K)$ & TP & $\begin{array}{l}4510 \pm 20 \\
(n=13)\end{array}$ & 10 & White fine ash & Hyp $\gg>$ Aug \\
\hline Whakatane $(W k)$ & OK-H & $\begin{array}{c}4830 \pm 20 \\
(n=21)\end{array}$ & 140 & $\begin{array}{l}\text { Firm, compact reddish-brown/orange fine } \\
\text { ash with coarse ash base (lower } 20 \mathrm{~mm} \text { ), } \\
\text { wavy boundary }\end{array}$ & Cgt $\gg$ Hyp, Hbe, Aug \\
\hline Tuhua $(T u)$ & TU & $\begin{array}{l}6130 \pm 30 \\
(n=10)\end{array}$ & 40 & $\begin{array}{l}\text { Olive-grey medium ash (gritty, soft, } \\
\text { putty-like) }\end{array}$ & Aeg $\gg$ Hyp \\
\hline Mamaku $(M a)$ & $\mathrm{OK}-\mathrm{H}$ & $\begin{array}{l}7250 \pm 20 \\
(n=22)\end{array}$ & 30 & $\begin{array}{l}\text { White-cream fine and medium ash, } \\
\text { wavy boundary }\end{array}$ & Hbe $\geq$ Hyp $\gg>$ Aug, ?Cgt \\
\hline Rotoma $(R m)$ & $\mathrm{OK}-\mathrm{H}$ & $\begin{array}{c}8530 \pm 10 \\
(n=45)\end{array}$ & 160 & $\begin{array}{l}\text { Reddish-brown medium ash over firm, yellow } \\
\text { fine ash at base, wavy boundary (thickness } \\
\text { of deposit varies from c. } 70-200 \mathrm{~mm} \text { ) }\end{array}$ & $\mathrm{Cgt} \gg \mathrm{Hbe}, \mathrm{Hyp}$ \\
\hline $\begin{array}{l}\text { Opepe }(O p) \\
\text { [Unit-E] }\end{array}$ & $\mathrm{TP}$ & $\begin{array}{l}9050 \pm 40 \\
(n=10)\end{array}$ & 90 & $\begin{array}{l}\text { Reddish-brown and creain fine ash (top } 30 \mathrm{~mm} \text { ) } \\
\text { over medium to coarse reddish-yellow ash }\end{array}$ & Hyp $\gg>$ Aug \\
\hline $\begin{array}{l}\text { Poronui }(P o) \\
\text { [Unit-C] }\end{array}$ & $\mathrm{TP}$ & $\begin{array}{l}9840 \pm 60 \\
(n=3)\end{array}$ & 40 & Yellowish-brown medium ash & Hyp $\gg$ Aug \\
\hline $\begin{array}{l}\text { Karapiti }(K p) \\
\text { [Unit-B] }\end{array}$ & TP & $\begin{array}{c}10030 \pm 90 \\
(n=2)\end{array}$ & 30 & Cream firm, fine ash (lensoidal) & Hyp $>>$ Aug, Hbe \\
\hline $\begin{array}{l}\text { Okupata }(\mathrm{Oa})^{\mathrm{f}} \\
\text { [Taurewa] }\end{array}$ & TG-R & 10100 & 50 & Cream-grey firm, fine ash (lensoidal) & $\mathrm{Opx} \mathrm{g}^{\mathrm{g}}>\mathrm{Cpx}$ \\
\hline $\begin{array}{l}\text { Konini }(K o) \\
{[\text { Egmont-11] }}\end{array}$ & EG-Tn & $\begin{array}{c}10150 \pm 50 \\
(n=4)\end{array}$ & 20 & Reddish-brown fine to very fine ash & Hbe $\geq C p x>O p x$ \\
\hline Waiohau $(W h)$ & $\mathrm{OK}-\mathrm{Tw}$ & $\begin{array}{c}11850 \pm 60 \\
(n=12)\end{array}$ & 420 & $\begin{array}{l}\text { Upper unit }(200 \mathrm{~mm} \text {, reworked tephra): white } \\
\text { fine to medium ash over pale orange-grey, } \\
\text { slightly laminated, coarse ash (variable } \\
\text { thickness); Lower unit ( } 220 \mathrm{~mm} \text {, primary tephra): } \\
\text { interlayered cream and grey fine ash beds }\end{array}$ & Hyp $>$ Hbe, Aug \\
\hline Puketarata $(P k)$ & MA & 13100 & 10 & $\begin{array}{l}\text { White fine to medium ash (variable thickness } \\
10-20 \mathrm{~mm} \text { ); black biotite flakes visible in } \\
\text { hand specimen }\end{array}$ & Bio $\gg$ Hbe, Hyp \\
\hline $\begin{array}{l}\text { Rerewhakaaitu } \\
(R k)\end{array}$ & OK-Tw & $\begin{array}{l}14700 \pm 95 \\
(n=4)\end{array}$ & 10 & $\begin{array}{l}\text { Bluish-grey coarse ash; black biotite flakes } \\
\text { visible in hand specimen }\end{array}$ & Bio $\gg$ Hbe, Hyp $\gg$ Aug \\
\hline
\end{tabular}

a OK, Okataina Volcanic Centre (-Tw, Mt Tarawera volcano; -H, Haroharo volcano); TP, Taupo Volcanic Centre; TU, Tuhua Volcanic Centre (Mayor I.); EG, Egmont Volcanic Centre (-Tn, Mt Taranaki volcano); TG, Tongariro Volcanic Centre (-R, Mt Ruapehu volcano); MA, Maroa Volcanic Centre.

${ }^{b}$ Conventional radiocarbon ages modified after Froggatt \& Lowe (1990), Wilson (1993), Alloway et al. (1995), and Lowe et al. (1998); ages on Okupata and Puketarata Tephras are estimated from sedimentation rates (see text). $n$, number of individual ages used to obtain error-weighted mean.

'See also Lowe \& Hogg (1986). Fine ash, <0.1 mm; medium ash, 0.1-0.5 mm; coarse ash, 0.5-2 mm; fine lapilli, 2-5 mm (approx.).

dDominant minerals in the magnetic fraction (separated by Frantz electromagnetic separator). Bio, biotite; Hyp, hypersthene; Aug, augite; Hbe, calcic hornblende; Cgt, cummingtonite; Aeg, aegirine; Opx, orthopyroxene; Cpx, clinopyroxene. All tephras contain FeTi oxides (opaque minerals); the Okataina-derived tephras additionally contain zircon. Glass, plagioclase feldspar \pm quartz predominate in non-magnetic fractions in all tephras. See also Lowe \& Hogg (1986).

eNames in square brackets are alternatives for each tephra (see text).

fProvisionally correlated with Okupata Member (?Ok 3 ) of Taurewa Formation (Donoghue et al. 1999).

gThe orthopyroxene here consists of two types, one pale green, the other dark orange and strongly zoned (under polarising microscope, plain light). 
Table 2 Electron microprobe analyses ${ }^{\mathrm{a}}$ of glass from tephras in the Kaipo Bog area.

\begin{tabular}{|c|c|c|c|c|c|c|c|c|c|}
\hline \multirow[b]{3}{*}{ Anal no } & \multicolumn{9}{|c|}{ Okataina-derived tephras } \\
\hline & \multicolumn{2}{|c|}{$K a$} & \multirow{2}{*}{$\begin{array}{c}W k \\
3\end{array}$} & \multirow{2}{*}{$\begin{array}{c}M a \\
4 \\
\end{array}$} & \multirow{2}{*}{$\begin{array}{c}R m \\
5\end{array}$} & \multicolumn{3}{|c|}{$W h$} & \multirow{2}{*}{$\begin{array}{c}R k \\
7\end{array}$} \\
\hline & $0^{b} \quad 1$ & 2 & & & & $6 \mathrm{a}$ & $6 \mathrm{~b}$ & $6 \mathrm{c}$ & \\
\hline $\mathrm{SiO}_{2}$ & $77.36(0.09)$ & $77.44(0.28)$ & $78.09(0.27)$ & $78.06(0.26)$ & $78.07(0.33)$ & $77.62(0.30)$ & $77.84(0.20)$ & $77.73(0.27)$ & $77.56(0.48)$ \\
\hline $\mathrm{Al}_{2} \mathrm{O}_{3}$ & $12.85(0.17)$ & $12.83(0.14$ & $12.36(0.15)$ & $12.30(0.13)$ & $12.32(0.18)$ & $12.73(0.22)$ & $12.60(0.17)$ & $12.67(0.20)$ & $12.85(0.30)$ \\
\hline $\mathrm{TiO}_{2}$ & $0.11(0.03)$ & $0.12(0.03)$ & $0.14(0.04)$ & $0.16(0.05)$ & $0.16(0.05)$ & $0.23(0.05)$ & $0.20(0.06)$ & $0.22(0.06)$ & $0.12(0.03)$ \\
\hline $\mathrm{FeO}^{\mathrm{c}}$ & $0.89(0.08)$ & $0.88(0.10)$ & $0.82(0.11)$ & $0.93(0.07)$ & $0.92(0.11)$ & $1.08(0.09)$ & $1.05(0.16)$ & $1.07(0.12)$ & $0.91(0.12)$ \\
\hline $\mathrm{MgO}$ & $0.09(0.03)$ & $0.08(0.03)$ & $0.13(0.04)$ & $0.13(0.03)$ & $0.15(0.03)$ & $0.17(0.05)$ & $0.13(0.04)$ & $0.15(0.04)$ & $0.11(0.05)$ \\
\hline $\mathrm{CaO}$ & $0.53(0.10)$ & $0.52(0.07)$ & $0.71(0.06)$ & $0.80(0.07)$ & $0.82(0.05)$ & $0.92(0.11)$ & $0.98(0.06)$ & $0.95(0.09)$ & $0.83(0.08)$ \\
\hline $\mathrm{Na}_{2} \mathrm{O}$ & $3.98(0.04)$ & $3.89(0.13)$ & $3.89(0.13)$ & $3.83(0.17)$ & $4.00(0.07)$ & $4.04(0.16)$ & $4.09(0.14)$ & $4.07(0.15)$ & $3.62(0.14)$ \\
\hline $\mathrm{K}_{2} \mathrm{O}$ & $4.05(0.13)$ & $4.09(0.25)$ & $3.71(0.08)$ & $3.63(0.10)$ & $3.39(0.14)$ & $3.06(0.18)$ & $2.97(0.06)$ & $3.02(0.14)$ & $3.82(0.36)$ \\
\hline $\mathrm{Cl}$ & $0.16(0.03)$ & $0.16(0.02)$ & $0.16(0.03)$ & $0.17(0.05)$ & $0.18(0.05)$ & $0.14(0.01)$ & $0.14(0.05)$ & $0.14(0.04)$ & $0.18(0.03)$ \\
\hline Water ${ }^{d}$ & $6.39(1.05)$ & $6.31(1.39)$ & $4.52(1.50)$ & $4.42(1.07)$ & $4.24(0.77)$ & $4.01(1.42)$ & $3.83(1.56)$ & $3.92(1.44)$ & $3.41(1.40)$ \\
\hline$n$ & 9 & 11 & 11 & 11 & 10 & 7 & 7 & 14 & 15 \\
\hline
\end{tabular}

Taupo-derived tephras

\begin{tabular}{|c|c|c|c|c|c|c|c|}
\hline \multicolumn{2}{|c|}{$T p(Y 5)$} & \multirow{2}{*}{$\begin{array}{c}W m(S I) \\
10\end{array}$} & \multicolumn{2}{|c|}{ Unit $-K$} & \multirow{2}{*}{$\begin{array}{c}O p(E) \\
12\end{array}$} & \multirow{2}{*}{$\begin{array}{c}P o(C) \\
13\end{array}$} & \multirow{2}{*}{$\begin{array}{c}K p(B) \\
14\end{array}$} \\
\hline 8 & 9 & & $11 \mathrm{a}$ & $11 \mathrm{~b}$ & & & \\
\hline
\end{tabular}

$\begin{array}{lllllllll}\mathrm{SiO}_{2} & 74.88(0.46) & 75.79(0.31) & 76.22(0.19) & 76.31(0.32) & 76.90(0.23) & 75.99(0.40) & 76.49(0.56) & 76.14(0.46)\end{array}$

$\begin{array}{llllllllll}\mathrm{Al}_{2} \mathrm{O}_{3} & 13.52(0.18) & 13.23(0.13) & 13.03(0.19) & 12.99(0.27) & 12.99(0.10) & 12.98(0.22) & 12.76(0.27) & 13.35(0.27)\end{array}$

$\begin{array}{lllllllll}\mathrm{TiO}_{2} & 0.30(0.11) & 0.24(0.04) & 0.21(0.05) & 0.24(0.03) & 0.19(0.03) & 0.22(0.04) & 0.21(0.06) & 0.24(0.06)\end{array}$

$\begin{array}{llllllllll}\mathrm{FeO}^{\mathrm{c}} & 2.07(0.14) & 1.83(0.11) & 1.79(0.11) & 1.70(0.19) & 1.60(0.08) & 1.85(0.14) & 1.68(0.13) & 1.65(0.11)\end{array}$

$\begin{array}{lllllllll}\mathrm{MgO} & 0.26(0.06) & 0.21(0.02) & 0.19(0.04) & 0.17(0.02) & 0.17(0.02) & 0.24(0.06) & 0.20(0.04) & 0.20(0.05)\end{array}$

$\begin{array}{llllllllll}\mathrm{CaO} & 1.57(0.14) & 1.37(0.11) & 1.43(0.10) & 1.41(0.14) & 1.30(0.07) & 1.63(0.13) & 1.45(0.19) & 1.45(0.11)\end{array}$

$\begin{array}{llllllllll}\mathrm{Na}_{2} \mathrm{O} & 4.29 & (0.16) & 4.37(0.19) & 4.11(0.10) & 4.13(0.11) & 3.75(0.12) & 3.90(0.08) & 3.88(0.15) & 4.05(0.14)\end{array}$

$\begin{array}{lllllllll}\mathrm{K}_{2} \mathrm{O} & 2.95(0.25) & 2.79(0.14) & 2.85(0.15) & 2.92(0.17) & 2.99(0.04) & 3.01(0.11) & 3.18(0.20) & 2.77(0.11)\end{array}$

$\begin{array}{llllllllll}\mathrm{Cl} & 0.15 & (0.03) & 0.17(0.03) & 0.16(0.03) & 0.14(0.03) & 0.11(0.02) & 0.18(0.05) & 0.16(0.03) & 0.16(0.03)\end{array}$

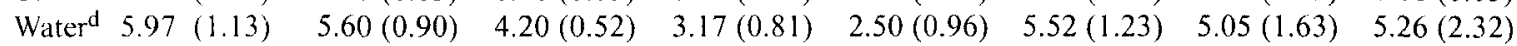

$\begin{array}{lllllllll}n & 10 & 9 & 10 & 9 & 13 & 11 & 10 & 11\end{array}$

Maroa-, Tuhua-, Tongariro-, and Egmont-derived tephras

\begin{tabular}{cccccccc}
\hline & $P k$ & & $T u$ & & $O a$ & \multicolumn{2}{c}{ Ko } \\
\cline { 8 - 9 } & 15 & & 17 & 18 & $19 \mathrm{a}$ & $19 \mathrm{~b}$ \\
\hline
\end{tabular}

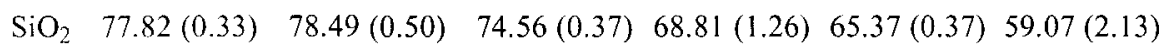

$\begin{array}{lllllllll}\mathrm{Al}_{2} \mathrm{O}_{3} & 12.59(0.20) & 12.28(0.10) & 9.48(0.27) & 15.64(0.89) & 17.43(0.53) & 20.49(2.97)\end{array}$

$\begin{array}{llllllll}\mathrm{TiO}_{2} & 0.08(0.05) & 0.08(0.02) & 0.29(0.08) & 0.79(0.11) & 0.72(0.09) & 0.59(0.17)\end{array}$

$\begin{array}{llllllll}\mathrm{FeO}^{\mathrm{c}} & 0.82(0.06) & 0.90(0.10) & 5.54(0.38) & 3.41 & (0.26) & 3.25(0.54) & 3.88(0.89)\end{array}$

$\begin{array}{llllllll}\mathrm{MgO} & 0.08(0.02) & 0.07(0.03) & 0.07(0.02) & 0.90(0.10) & 1.04(0.26) & 1.67(0.44)\end{array}$

$\begin{array}{llllllll}\mathrm{CaO} & 0.66(0.06) & 0.64(0.04) & 0.27(0.04) & 3.38(0.72) & 2.79(0.50) & 7.08(1.79)\end{array}$

$\begin{array}{llllllll}\mathrm{Na}_{2} \mathrm{O} & 3.56(0.21) & 3.23(0.38) & 5.34(0.25) & 3.94(0.17) & 4.98(0.37) & 4.64(0.17)\end{array}$

$\begin{array}{llllllll}\mathrm{K}_{2} \mathrm{O} & 4.20(0.13) & 4.17(0.48) & 4.25(0.19) & 2.97(0.17) & 4.24(0.23) & 2.46(0.97)\end{array}$

$\begin{array}{llllllll}\mathrm{Cl} & 0.19(0.03) & 0.15(0.03) & 0.22(0.04) & 0.16(0.04) & 0.19(0.04) & 0.13(0.10)\end{array}$

$\begin{array}{llllllll}\text { Water }^{\mathrm{d}} & 1.99(1.29) & 5.07(1.09) & 3.38(1.00) & 3.34 & (2.28) & 2.36(0.78) & 1.10(0.04)\end{array}$

$\begin{array}{lllllll}n & 11 & 12 & 11 & 11 & 8 & 2\end{array}$

a Means and standard deviations (in parentheses) of $n$ analyses (individual glass shards) normalised to $100 \%$ loss-free (wt $\%$ ). Analysts by wavelength-dispersive Jeol JXA-733 Superprobe at the Analytical Facility, Victoria University of Wellington, were undertaken hy D. A. Manning (all except $I I b$ and 16 ) using various glass and elemental standards to correct for machine drift, defocused beam diameter $10-15 \mu \mathrm{m}$, current $8 \mathrm{nA}$, and accelerating voltage $15 \mathrm{kV}$ (see Froggatt 1983; Lowe 1988b; Manning 1995). Analyses were calculated (except $11 b, 16$ ) from $11 \times 2$ s counts across the peak, curve integrated; anal. $(11 b)$ and ( 16 ) (analyst D. J. Lowe) we e calculated from $3 \times 10 \mathrm{~s}$ count times at the peak, meaned. Tephra abbreviations are given in Table 1 .

${ }^{b}$ All analyses are on samples from the Kaipo Bog section except anal. (2) and (9) which are from nearby Lake Waikaremoana (Fig. Newnham et al. 1998a), and anal. (16) which is from Lake Rotomanuka (Waikato region; Lowe 1988b); anal. (11b) is from the initial Kaipo section of Lowe \& Hogg (1986). Anal. ( $6 a)$ and $(6 b)$ are from upper and lower parts of Waiohau Tephra respectively, and (6b) is these data combined. Analysis $(19 b)$ is a trachyandesitic subpopulation within Konini Tephra. Poronui Tephra additionally containcd one dacitic shard, and Okupata and Unit-K Tephras each contained one Okataina-derived rhyolitic shard (not reported).

c Total Fe as FeO.

${ }^{d}$ Difference between original analytical total and 100 . 
mineralogical assemblages typical of Taupo-derived Holocene eruptives (Froggatt \& Lowe 1990). Constituent glass shard analyses (anal. 8-14, Table 2) are all rhyolitic and compositionally closely matched with those characteristic of a Taupo source and with named correlatives (Lowe 1988a, b; Stokes \& Lowe 1988; Froggatt \& Rogers 1990; Stokes et al. 1992; Alloway et al. 1994; Shane \& Froggatt 1994; Newnham et al. 1995a, 1998a; Eden \& Froggatt 1996). Ranges for selected oxides (mean values) are $\mathrm{SiO}_{2} 74.9$ $6.5 \%, \mathrm{TiO}_{2} 0.2-0.3 \%, \mathrm{FeO}_{\text {total }} 1.7-2.1 \%, \mathrm{MgO} 0.2-0.3 \%$, and $\mathrm{CaO} 1.4-1.6 \%$.

\section{Maroa-derived tephra}

This is provisionally referred to as Puketarata Tephra following Froggatt \& Lowe (1990). Its identification at Kaipo Bog is based on the predominance of biotite in its firromagnesian mineralogical assemblage (Topping \& Kohn 1973; Froggatt \& Lowe 1990; Brooker et al. 1993) and its unusual glass shard composition (anal. 15, Table 2). The very low $\mathrm{TiO}_{2}$ and $\mathrm{MgO}$ concentrations (both $<0.1 \%$ ) correspond t. . similarly low levels in rhyolitic glass from a possible distal correlative at Lake Rotomanuka in the Waikato region (anal. I 5), in glass from near-source Puketarata Tephra, and with analyses on residual glass of lava from Puketarata dome (Jwart et al. 1968; Lowe 1988b). The relatively high $\mathrm{K}_{2} \mathrm{O}$ le vels ( $>4 \%$ ) are similarly distinctive (Lowe 1988a; Stokes \& Lowe 1988). Initially, we provisionally identified this te phra layer at Kaipo as the Okataina-derived Rotorua Tephra because of its stratigraphic position between Waiohau and Rerewhakaaitu Tephras, and because the upper part of $\mathrm{R}$ storua Tephra may contain considerable biotite (Froggatt \& Lowe 1990). However, the glass composition does not accord with that previously published for Rotorua Tephra (Cireen \& Lowe 1985; Lowe 1988a, b; Stokes et al. 1992). $\mathrm{R}$ storua Tephra is distinctive because, paradoxically, its glass is compositionally similar to that of Holocene eruptives from Tupo (rather than Okataina) volcano. In making our cc rrelation with Puketarata Tephra, we assume that all glass throughout the Rotorua eruptive sequence is uniformly "Taupo-like" in composition.

The stratigraphic relationship of Puketarata Tephra to ce rtain other tephras is unclear (cf. Vucetich \& Pullar 1973; Tr pping \& Kohn 1973; Lowe 1988b), and it has had limited chronostratigraphic value. Lowe (1988b) suggested, from its occurrence as a composite, disseminated deposit between Rotoaira (which underlies Rotorua Tephra) and Rerewhakaaitu Tephras at Lake Rotomanuka, that it was erupted c. $14000{ }^{14} \mathrm{C}$ yr BP. However, we obtain here an age for "Fuketarata Tephra" at Kaipo Bog of c. $13100{ }^{14} \mathrm{C}$ yr BP (sce below). This indicates that either the previous age estimate from Lake Rotomanuka was too old or that perhaps two tephras, of identical glass composition, were erupted c. $1000 \mathrm{yr}$ apart from the Puketarata craters of the Maroa Volcanic Centre (i.e., one at c. 14000 and another at c. $13100^{14} \mathrm{C}$ yr BP).

\section{Tuhua-derived tephra}

Tl is is referred to as Tuhua Tephra following the no nenclature of Hogg \& McCraw (1983) and Froggatt \& Lowe (1990). It has a unique ferromagnesian mineralogical assemblage dominated by sodic phases, especially aegirine (Table 1), and a distinctive peralkaline (molar $\left[\mathrm{Na}_{2} \mathrm{O}+\mathrm{K}_{2} \mathrm{O}\right]$ ) $\mathrm{Al} . \mathrm{O}_{3}>1$ ) major element composition (anal. 17, Table 2), consistent with previous mineralogical and glass compositional analyses of this tephra (Lowe 1988a, b; Stokes \& Lowe 1988; Froggatt \& Lowe 1990; Newnham \& Lowe 1991; Pillans \& Wright 1992; Newnham et al. 1995b). The glass, although silicic, has relatively low amounts of $\mathrm{Al}_{2} \mathrm{O}_{3}(9.5 \%)$ and $\mathrm{CaO}(0.3 \%)$ but characteristically high amounts of $\mathrm{FeO}_{\text {total }}(5.5 \%)$ and $\mathrm{Na}_{2} \mathrm{O}(5.3 \%)$.

\section{Tongariro-derived tephra}

This tephra was previously identified by Lowe \& Hogg (1986) at Kaipo as an unnamed member of the Okupata Tephra Formation of Topping (1973); and Lowe (1988b) implied correlation with the informally named Tongariroderived "Okupata-1" tephra layer in the Waikato region. The tephra at Kaipo Bog is provisionally correlated here with Okupata Member of Taurewa Formation, newly defined by Donoghue et al. (1999). The Mt Ruapehu-derived Taurewa Formation comprises two members: Okupata Member (tephra-fall deposits) and Pourahu Member (pyroclastic-flow deposits) (Donoghue et al. 1995a, b, 1999). At Kaipo, the tephra contains orthopyroxene and clinopyroxene (Table 1), an assemblage typical of many Tongariro-derived eruptives (Lowe 1988a, b; Froggatt \& Rogers 1990; Cronin et al. 1996; Donoghue \& Neall 1996; Donoghue et al. 1991, 1995a, 1997, 1999; Nakagawa et al. 1998). The dacitic glass ( $\left.\mathrm{SiO}_{2} 68.8 \%\right)$ (anal. 18, Table 2) is compositionally consistent with a source in Tongariro Volcanic Centre and generally matches analyses on Okupata Member glass reported by Donoghue et al. (1999) (cf. microprobe analyses of "coarse ash" sample, Hydro Access Rd-10 section; Donaghue et al. 1999). Proportions of $\mathrm{Al}_{2} \mathrm{O}_{3}(15.6 \%), \mathrm{TiO}_{2}(0.8 \%), \mathrm{FeO}_{\text {total }}(3.4 \%)$, $\mathrm{MgO}(0.9 \%)$, and $\mathrm{CaO}(3.4 \%)$ are characteristically high; the moderate $\mathrm{K}_{2} \mathrm{O}(3 \%$ ) content helps to exclude the glass from an Egmont source (Lowe 1988a, b; Stokes \& Lowe 1988).

\section{Egmont-derived tephra}

This tephra is considered to be a correlative of Konini Tephra as defined by Alloway et al. (1995). It is also correlated with the informal unit "Egmont-11" of Lowe (1988b), which underlies "Okupata-1" in the Waikato region. The tephra layer at Kaipo has a ferromagnesian mineralogy dominated by hornblende and clinopyroxene with lesser amounts of orthopyroxene (Table 1), typical of many Egmont-derived eruptives (Kohn \& Neall 1973; Lowe 1988b; Price et al. 1999). The very fine grained texture of the deposit is consistent with it being transported a relatively long distance-Kaipo Bog is c. $300 \mathrm{~km}$ from Mt Egmont (Taranaki). The trachydacitic glass composition (anal. 19a, Table 2) supports an Egmont affinity (e.g., Lowe 1988a, b; Stokes \& Lowe 1988; Pillans \& Wright 1992; Eden \& Froggatt 1996; Price et al. 1999), especially the high $\mathrm{K}_{2} \mathrm{O}$ content $(4.2 \%)$. The glass is relatively high in $\mathrm{TiO}_{2}(0.7 \%)$, $\mathrm{Al}_{2} \mathrm{O}_{3}(17.4 \%), \mathrm{FeO}_{\text {total }}(3.3 \%), \mathrm{MgO}(1.0 \%)$, and $\mathrm{Na}_{2} \mathrm{O}$ $(5.0 \%)$

The subpopulation of low- $\mathrm{K}_{2} \mathrm{O}$, trachyandesitic glass (anal. 19b, Table 2) in the Konini Tephra layer has uncertain origin. The shards may be derived from the Tongariro Volcanic Centre, suggesting that there has been admixing between deposits from closely spaced eruptions (Lowe 1988a). Alternatively, they may represent a less-differentiated magmatic fraction associated with the Konini or other eruption at Egmont (e.g., see Shane in press). 


\section{CHRONOLOGY}

Twenty-three radiocarbon dates have been obtained from the Kaipo sequence: 15 dates were reported by Lowe \& Hogg (1986) and 8 further dates are reported here (Fig. 2; Table 3). All but one of the dates were assayed by the University of Waikato Radiocarbon Dating Laboratory (prefixed Wk) using conventional liquid scintillation spectometry; the Rafter (New Zealand) Radiocarbon Laboratory undertook the analysis of one sample (NZA7751) using accelerator mass spectrometry. The ages, corrected for isotopic fractionation, are reported in conventional radiocarbon years $\left({ }^{14} \mathrm{C}\right.$ yr $) \mathrm{BP}$.

The ages progressively increase in age down the section with no stratigraphic inversions from tephra to tephra, and thus very little mixing or contamination ha occurred in the sequence. Coarse and fine peat fraction are demonstrably contemporaneous (Lowe \& Hogg 1986 and duplicate samples accord closely with one anothe (Table 3). Only three samples, Wk493-495, are cor sidered unreliable and hence omitted from furthit consideration. Our revised stratigraphy shows that thes three samples, originally reported by Lowe \& Hog : (1986) as being "too young" with respect to the ag: assigned to the underlying Rotoma Tephra, came fris 1 part of the section that had been locally truncated.

In addition to the ages obtained by radiocarbon datin , the 16 tephra layers provide a further set of independe: $t$ ages for the Kaipo sequence because all but two of the 1 have been dated elsewhere, many with numerous associat 1

Table 3 Radiocarbon ages from Kaipo Bog, listed stratigraphically.

\begin{tabular}{|c|c|c|c|c|c|}
\hline Lab. No. ${ }^{a}$ & $\begin{array}{c}\text { Age } \\
\left({ }^{14} \mathrm{C} \text { yr BP }\right)^{b}\end{array}$ & $\begin{array}{l}\delta^{13} \mathrm{C} \\
(\%)\end{array}$ & $\begin{array}{c}\text { Sample type } \\
\text { (thickness, mm) }\end{array}$ & Stratigraphic position (see Fig. 2) & Comment (reference) ${ }^{\mathrm{d}}$ \\
\hline Wk499 & $2910 \pm 60$ & -25.7 & P-r $(20)$ & Overlies Waimihia Tephra (S1) & $(1,2)$ \\
\hline Wk500 & $3040 \pm 50$ & -26.4 & $P-f(20)$ & Overlies Waimihia Tephra (S1) & Same sample as Wk499 $(1,2)$ \\
\hline Wk498 & $3250 \pm 70$ & -26.4 & P-b (20) & Underlies Waimihia Tephra (S1) & $(1,2)$ \\
\hline Wk496 & $4490 \pm 60$ & -26.9 & P-b $(20)$ & Underlies Unit-K ("Hinemaiaia") & $(1,2)$ \\
\hline Wk497 & $4530 \pm 60$ & -26.4 & P-b (20) & Underlies Unit-K ("Hinemaiaia") & $\begin{array}{l}\text { Same sampling position as } \mathrm{Wk} 496 \\
\text { (duplicate) }(1,2)\end{array}$ \\
\hline Wk501 & $4860 \pm 70$ & -26.4 & P-b $(20)$ & Underlies Whakatane Tephra & $(1,2)$ \\
\hline$W k 4413$ & $7380 \pm 70$ & -26.4 & P-b (20) & Underlies Mamaku Tephra & (3) \\
\hline$(W k 493)^{f}$ & $5440 \pm 170$ & -25.8 & P-r (20) & Overlies Rotoma Tephra & $\begin{array}{l}\text { Unreliable with respect to Rotoma } \\
\text { Tephra }(1,2)\end{array}$ \\
\hline$(W k 494)^{f}$ & $7380 \pm 80$ & -26.8 & $P-f(20)$ & Overlies Rotoma Tephra & $\begin{array}{l}\text { Same sample as Wk493, unreliable } \\
\text { with respect to Rotoma Tephra }(1,2\end{array}$ \\
\hline$(\mathrm{Wk} 495)^{\mathrm{r}}$ & $7560 \pm 100$ & -26.2 & P-b (20) & Overlies Rotoma Tephra & $\begin{array}{l}\text { Same sampling position as Wk494 } \\
\text { (duplicate), unreliable with respec. } \\
\text { Rotoma Tephra }(1,2)\end{array}$ \\
\hline Wk492 & $8710 \pm 80$ & -26.7 & P-b $(20)$ & Overlies Opepe Tephra (E) & $(1,2)$ \\
\hline Wk491 & $9560 \pm 80$ & -27.0 & P-b (20) & Overlies Poronui Tephra (C) & $(1,2)$ \\
\hline Wk352 & $9960 \pm 90$ & -28.5 & P-f $(20)$ & Underlies Poronui Tephra (C) & $(1,2)$ \\
\hline Wk351 & $10160 \pm 130$ & -29.4 & P-r $(20)$ & Underlies Poronui Tephra (C) & Same sample as Wk352 $(1,2)$ \\
\hline NZA7761 & $10146 \pm 76$ & -29.1 & P-b (40) & Underlies Konini Tephra & AMS date - dual lab. no. Wk 54049 \\
\hline Wk263 & $10600 \pm 90$ & -29.6 & P-b (20) & $\begin{array}{l}\text { Basal peat overlying pale } \\
\text { brownish-grey mud unit }\end{array}$ & $\begin{array}{l}\text { Equivalent stratigraphic position to } \\
\quad W \mathrm{k} 5162(1,2)\end{array}$ \\
\hline Wks 5162 & $10790 \pm 70$ & $-30,0$ & P-b (30) & $\begin{array}{l}\text { Basal peat overlying pale } \\
\text { brownish-grey mud unit }\end{array}$ & (3) \\
\hline Wk5164 & $11360 \pm 210$ & -31.8 & $M-p(40)$ & Dark brown peaty mud layer "B" & (3) \\
\hline Wk264 & $11500 \pm 80$ & -29.1 & $M-p(20)$ & Dark brown peaty mud layer "A" & $(1,2)$ \\
\hline Wk5403 & $12180 \pm 260$ & -31.1 & $M-s p(40)$ & $\begin{array}{l}\text { Base of pale brownish-grey mud } \\
\text { unit overlying Waiohau Tephra }\end{array}$ & (3) \\
\hline Wk4414 & $12420 \pm 90$ & -28.4 & P-b $(30)$ & Underlies Waiohau Tephra & (3) \\
\hline Wk5 163 & $13420 \pm 80$ & -31.2 & $M-p(40)$ & $\begin{array}{l}\text { Base of peat transitional to basal } \\
\text { olive-blue sandy mud unit }\end{array}$ & (3) \\
\hline Wk5165 & $14700 \pm 160$ & -30.5 & $M-p(30)$ & Overlies Rerewhakaaitu Tephra & $(3)$ \\
\hline
\end{tabular}

aWk, University of Waikato Radiocarbon Dating Laboratory number; NZ, Rafter (New Zealand) Radiocarbon Dating Laboratory nuın: er.

${ }^{b}$ Conventional radiocarbon years BP based on the old (Libby) half-life \pm 1 SD from counting statistics. Errors for dates referenced 3 ) are multiplied by laboratory error multiplier $(K)$ of $1.217 . \delta^{13} \mathrm{C}$ measurements are $\pm 0.2 \%$.

(P-b, bulk peat; P-r, roots (>c. $1 \mathrm{~mm}$ diameter) extracted from bulk peat; P-f, fine peat residual from bulk peat after root extract .n; M-p, peaty mud; M-sp, slightly peaty mud. All samples were washed in hot $10 \% \mathrm{HCl}$, rinsed and dried prior to assay.

dReterences: 1, Lowe \& Hogg (1986); 2, Hogg et al. (1987); 3, this study.

"Alternative tephra names given in parentheses (see text, Table 1).

${ }^{f}$ Ages are unreliable with respect to eruption of Rotoma Tephra (too young) but consistent with a hiatus in the stratigraphy rif he original section sampled by Lowe \& Hogg (1986) in which Tuhua and Mamaku Tephras were missing from the zone between Whaka! me and Rotoma Tephras.

¿Sample $\mathrm{CO}_{2}$ prepared by Waikato laboratory, assayed using AMS by Rafter laboratory (both laboratory numbers apply). 
dates. Ages assigned to the tephras are summarised in Fig. 2 and Table 1, and are discussed below, from youngest to ")ldest. We include also in this section provisional "midtange" estimates (2-sigma level) of the calendar age (cal yr BP) for each tephra, based on OxCal (Bronk Ramsey 1995). These estimates, derived from the terrestrial calibration curves of Stuiver et al. (1998), are necessarily approximate hecause of multiple intercepts, errors on both ages and curves, and other factors (Stuiver \& van der Plicht 1998). Some of the calibrated ages span hundreds of years in range. Corrections for the interhemispheric offset (McCormac et il. 1998) were applied to the estimates for Kaharoa and Taupo Tephras only.

\section{Tephra ages}

Kaharoa Tephra is aged $665 \pm 15^{14} \mathrm{C}$ yr BP, the errorveighted mean (EM) age obtained from cluster analysis of 22 radiocarbon ages minus 8 statistical outliers (Lowe et al. 1998). The calibrated age is c. $600 \mathrm{cal}$ yr BP (c. AD 1350) (.owe et al. 1998).

Txupo Tephra (Subunit-Y5) has an EM age $(n=41)$ of 1850 $\pm 10^{14} \mathrm{C}$ yr BP (Froggatt \& Lowe 1990), consistent with an EM age $(n=7)$ obtained on short-lived leaves and seeds of $1345 \pm 19^{14} \mathrm{C}$ yr BP (Lowe \& de Lange in press). The culibrated age is c. 1750 cal yr BP (c. AD 200) (Lowe \& de L ange in press). Other possible calendar dates for Taupo Tephra are AD 186 (based on interpretations of historical rtcords; Wilson et al. 1980), AD $181 \pm 2$ (from ice-core ricords; Zielinksi et al. 1994), c. AD 177 (1-sigma range AD 166-195) (from dendrochronology; Froggatt \& Lowe 1990), and $\mathrm{AD} 232 \pm 15$ (from dendrochronology; Sparks et al. 1995).

Haimihia Tephra (Subunit-S1) has an EM age $(n=17)$ of $3.230 \pm 20{ }^{14} \mathrm{C}$ yr BP. We calculated this by re-evaluating the 17 ages reported for Waimihia Tephra by Froggatt \& L. owe (1990), three of which are now known to relate to the older Stent tephra (Alloway et al. 1994). Two new ages ohtained by Wilson (1993) on charcoal and one by Holdaway \& Beavan (1999) on moa eggshell were included in the dt termination of the mean: $3340 \pm 50{ }^{14} \mathrm{C}$ yr BP (Wk1840), $3: 90 \pm 50{ }^{14} \mathrm{C}$ yr BP (Wk1841), and $3005 \pm 68{ }^{14} \mathrm{C}$ yr BP (NZA7701). Three ages (Wk498, 499, 500) obtained by Lowe \& Hogg (1986) from samples associated with Waimihia Tephra at the original Kaipo section support our adopted age (Fig. 2). The calibrated age is c. $3450 \mathrm{cal} \mathrm{yr}$ $\mathrm{BP}$.

Unit- $K$, the most voluminous and widely dispersed of the previously so-called "Hinemaiaia" units (Wilson 1993), has an EM age $(n=13)$ of $4510 \pm 20^{14} \mathrm{C}$ yr BP. This age is based on a re-evaluation of the 12 ages used by Froggatt $\&$ Lc we (1990) (two ages were discarded as outliers, NZ3160, $3161)$ together with a new age on charcoal, $4630 \pm 200{ }^{14} \mathrm{C}$ yr BP (Wk1835), reported by Wilson (1993), and two on peat, $4330 \pm 80^{14} \mathrm{C}$ yr BP (Wk1495) and $4600 \pm 70{ }^{14} \mathrm{C} \mathrm{yr}$ Bl' (Wk2152), reported by Alloway et al. (1994) and Nt wnham et al. (1995a). It is consistent with two ages (W k496, 497) obtained by Lowe \& Hogg (1986) at Kaipo for this tephra. The calibrated age is c. $5200 \mathrm{cal}$ yr BP.

Whakatane Tephra has an EM age $(n=21)$ of $4830 \pm 20$ ${ }^{14} \mathrm{C}$ yr BP (Froggatt \& Lowe 1990), in close agreement with the age (Wk501) obtained at Kaipo by Lowe \& Hogg (1986). It has a calibrated age of c. $5550 \mathrm{cal}$ yr BP.

Tuhua Tephra has an EM age $(n=10)$ of $6130 \pm 30{ }^{14} \mathrm{C}$ yr BP (Froggatt \& Lowe 1990), equivalent to a calibrated age of c. $7000 \mathrm{cal}$ yr BP.

Mamaku Tephra has an EM age $(n=22)$ of $7250 \pm 20{ }^{14} \mathrm{C}$ yr BP (Froggatt \& Lowe 1990), which is close to the age of $7380 \pm 70{ }^{14} \mathrm{C}$ yr BP (Wk4413) obtained on peat below this tephra (Fig. 2). The calibrated age is c. $8050 \mathrm{cal}$ yr BP.

Rotoma Tephra has an EM age $(n=45)$ of $8530 \pm 10^{14} \mathrm{C} \mathrm{yr}$ BP (Froggatt \& Lowe 1990), equivalent to a calibrated age of c. $9500 \mathrm{cal} \mathrm{yr} \mathrm{BP.}$

Opepe Tephra (Unit-E) has an EM age $(n=10)$ of $9050 \pm$ $40{ }^{14} \mathrm{C}$ yr BP (Froggatt \& Lowe 1990), which was adopted also by Wilson (1993). It is consistent with the age (Wk492) obtained on this tephra at Kaipo by Lowe \& Hogg (1986). The calibrated age is c. $10200 \mathrm{cal}$ yr BP.

Poronui Tephra (Unit-C) has an EM age $(n=3)$ of $9840 \pm$ $60{ }^{14} \mathrm{C}$ yr BP (recalculated from Froggatt \& Lowe 1990). It is derived from the three ages (Wk491, 351, 352) obtained by Lowe \& Hogg (1986) at Kaipo for this tephra. Wilson (1993) adopted an age of $9800{ }^{14} \mathrm{C}$ yr BP for Poronui Tephral Unit-C. The calibrated age is c. $11350 \mathrm{cal} \mathrm{yr} \mathrm{BP.}$

Karapiti Tephra (Unit-B) has an EM age $(n=4)$ of $9820 \pm$ $80{ }^{14} \mathrm{C}$ yr BP (Froggatt \& Lowe 1990). At face value there is no time difference between this age and that adopted for Poronui Tephra. However, the accumulation of peat between the two tephras at Kaipo and the development of a (weak) paleosol on Karapiti Tephra/Unit-B near the source (Wilson 1993) indicate that some time must have elapsed between the Karapiti and Poronui eruptions. Consequently, we adopt here an EM age $(n=2)$ of $10030 \pm 90{ }^{14} \mathrm{C}$ yr BP for Karapiti Tephra, which is based on two charcoal-derived ages, 9910 $\pm 130{ }^{14} \mathrm{C}$ yr BP (NZ4847) and $10150 \pm 130{ }^{14} \mathrm{C}$ yr BP (Wk 1846), as used by Wilson (1993). (The EM age derived from pooling all available ages $(n=5)$ is $9910 \pm 70{ }^{14} \mathrm{C}$ yr BP.) The adopted age has an equivalent calibrated age of c. $11700 \mathrm{cal}$ yr BP.

Okupata Member (of Taurewa Formation) is here assigned an age of c. $10100{ }^{14} \mathrm{C}$ yr BP, which we estimated from rates of sedimentation at Kaipo (Fig. 3). Although no direct dates are available for this tephra near its source, it is constrained chronostratigraphically by Karapiti and Waiohau Tephras to between c. 10000 and $11850{ }^{14} \mathrm{C}$ yr BP (Donoghue et al. 1995b, 1999). Its likely distal correlative in the Waikato region, "Okupata-1", was assigned an age of c. $10100{ }^{14} \mathrm{C}$ yr BP based on a series of dates on stratigraphically adjacent deposits in Lake Maratoto (Hogg et al. 1987; Lowe 1988b). These dates included $10000 \pm$ $120{ }^{14} \mathrm{C}$ yr BP (Wk232) and $10120 \pm 100{ }^{14} \mathrm{C}$ yr BP (Wk213) from tephras just above "Okupata- 1 ", and $10100 \pm 100{ }^{14} \mathrm{C}$ yr BP (Wk519) on "Egmont-11" (i.e., Konini Tephra) just below it (Lowe 1988b). The calibrated age is estimated at c. $11750 \mathrm{cal}$ yr BP.

Konini Tephra has an EM age $(n=4)$ of $10150 \pm 50{ }^{14} \mathrm{C}$ yr BP. This is based on two ages obtained on Konini Tephra in 


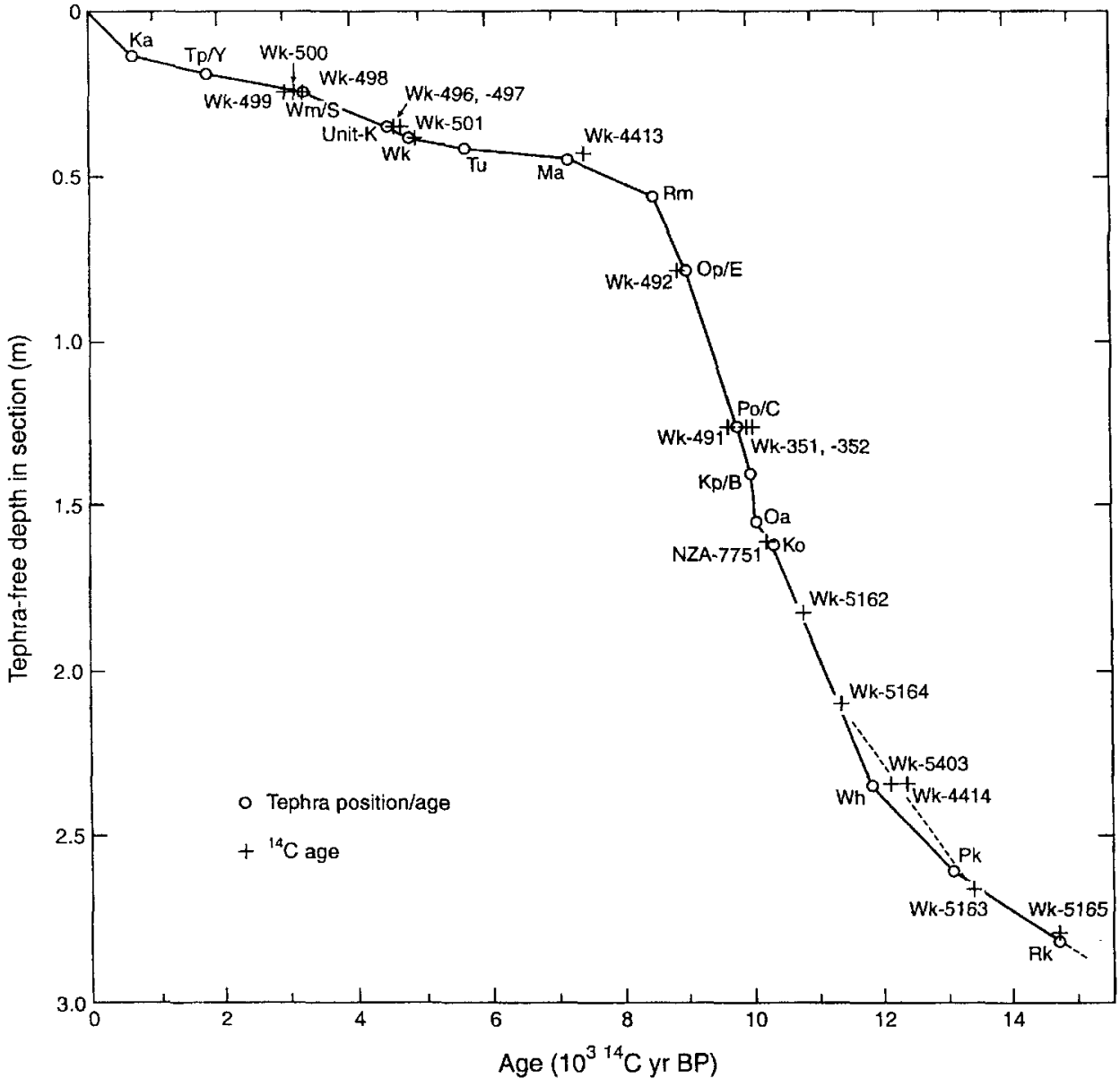

Fig. 3 Sediment age-depth cut for the Kaipo Bog sequent: Abbreviations for tephras : $\mathrm{r}$ given in Table 1 . The solid cur is drawn through the tephra-ig data points and Wk5163; th dashed curve is drawn through $t$ mid-point of Wk5403 an Wk4414. The ${ }^{14} \mathrm{C}$-based $a \xi$ points $(+)$ are closely aligned the tephra-age based curve. the Taranaki region of $10150 \pm 100{ }^{14} \mathrm{C}$ yr BP (NZ3153) and $10450 \pm 200{ }^{14} \mathrm{C}$ yr BP (NZ5410) (Alloway et al. 1995), and one on its likely correlative, "Egmont-11", in the Waikato region of $10100 \pm 100{ }^{14} \mathrm{C}$ yr BP (Wk519) (Lowe 1988b). We obtained a corroborative age (NZA7751) on this tephra at the Kaipo section of $10146 \pm 76^{14} \mathrm{C}$ yr BP (Fig. 2), and this was included in the mean age calculation. The calibrated age is c. $11850 \mathrm{cal}$ yr BP.

The four tephra layers just discussed-Poronui, Karapiti, Okupata, and Konini-are individually not able to be separated on the basis of radiocarbon age alone, probably in part because they fall within one of the "radiocarbon plateau" episodes that occurs at c. $10000{ }^{14} \mathrm{C}$ yr BP (Ammann \& Lotter 1989; Björck et al. 1998; Stuiver et al. 1998). However, we have been able to apply reasonable age estimates to these tephras at Kaipo because they occur in stratigraphic succession with peat deposited between them, so that the lowermost tephra is clearly older than the uppermost one by possibly some hundreds of years. The ages we have assigned to these tephras are further constrained by the dates newly obtained on the underlying pale brownishgrey muds (Wk5162, 5164), which are themselves supported by previous dates from this part of the sequence (Wk263, 264) as reported by Lowe \& Hogg (1986) (Fig. 2).

Waiohau Tephra has an EM age $(n=12)$ of $11850 \pm 60{ }^{14} \mathrm{C}$ yr BP based on Froggatt \& Lowe's (1990) analysis. Subsequent statistical analyses of all available ages on
Waiohau Tephra generated mean ages that do not difl $r$ significantly from this age (T. F. G. Higham pers. con $t$. 1998). The age of $11850 \pm 60{ }^{14} \mathrm{C}$ yr BP is a little yourg $r$ than the two new ages of $12180 \pm 260^{14} \mathrm{C}$ yr BP (Wk54C) and $12420 \pm 90{ }^{14} \mathrm{C}$ yr BP (Wk4414) returned on samp? 's from above and below Waiohau Tephra, respectively (Fig ). It is possible that these new ages contain a component if older carbon derived from catchment inwashing durirg a period of instability at around the time of deposition if Waiohau Tephra (cf. Yoshikawa et al. 1988; McGlone 199. ), and hence may overestimate the age of the tephra by seve: 11 hundred years. Evidence for such inwashing, hence probal e "old" carbon contamination, includes the overthickeri $\mathrm{g}$ (reworking) of the upper part of the Waiohau Tephra, $1 \mathrm{e}$ lithological change from peat to mud following s deposition, and the relatively high proportion of degrac $\mathrm{d}$ pollen grains in samples taken from immediately above it (Newnham \& Lowe in prep.). The calibrated age for Waict $u$ Tephra is c. 13800 cal yr BP.

Puketarata Tephra has not previously been dated direc ly but an age of c. $14000{ }^{14} \mathrm{C}$ yr BP was obtained by Lo ve (1988b) from micro-tephra analysis in the Waikato regi $n$. This estimate clearly is incompatible with the age of $134: 0$ $\pm 80{ }^{14} \mathrm{C}$ yr BP (Wk5163) obtained from a slice of peat 4. $80 \mathrm{~mm}$ below the base of "Puketarata Tephra" as identif :d at Kaipo Bog (Fig. 2). We have estimated an age of c. 13110 ${ }^{14} \mathrm{C}$ yr BP for the Puketarata Tephra layer at Kaipo us ig sedimentation rates constrained by the Wk5163 and Waiol tu 
Tephra (11 $850{ }^{14} \mathrm{C}$ yr BP) datums (Fig. 3). The calibrated age here is c. $15800 \mathrm{cal} \mathrm{yr} \mathrm{BP.}$

Rerewhakaaitu Tephra has an EM age $(n=3)$ of $14700 \pm$ $10^{14} \mathrm{C}$ yr BP (from Froggatt \& Lowe 1990), which is identical to the age (Wk5165) of $14700 \pm 160{ }^{14} \mathrm{C} \mathrm{yr} \mathrm{BP}$ obtained on peaty mud immediately overlying this tephra (Fig. 2). Including Wk5165 in the calculation gives an EM age $(n=4)$ of $14700 \pm 95{ }^{14} \mathrm{C}$ yr BP, which we adopt here. The calibrated age is c. $17700 \mathrm{cal} \mathrm{BP}$.

The base of the sequence, a few centimetres below Rerewhakaaitu Tephra, is likely to be close to c. $15000{ }^{14} \mathrm{C}$ vr BP in age, equivalent to c. $18000 \mathrm{cal} \mathrm{yr} \mathrm{BP.}$

\section{Radiocarbon versus tephrochronological ages}

We have constructed a sediment age-depth curve for the Kaipo sequence (Fig. 3). It demonstrates clearly that the tadiocarbon ages obtained at Kaipo are closely aligned to the tephra-age curve derived from tephrochronology, as discussed above. Thirty-four radiocarbon dates, 20 on peats and 14 mean ages associated with the tephra layers, have heen applied to the Kaipo sequence. These 14 tephra-based dates are derived, in turn, from some 250 radiocarbon dates (n the tephras in environments elsewhere (e.g., Hogg et al. 1987; Froggatt \& Lowe 1990; Wilson 1993), that is, around 270 dates have, in effect, been brought to bear on the Kaipo sequence. The 34 radiocarbon dates applied to the sequence represent an average of one date every c. $80 \mathrm{~mm}$ of sediment (excluding tephra deposits), equivalent to c. $430 \mathrm{yr}$ of sedimentation.

\section{Sedimentation rates and implications for lateglacial paleoenvironments}

he average sedimentation rate (on a tephra-free basis and t.sing radiocarbon years) for the entire Kaipo sequence is $1.19 \mathrm{~mm} / \mathrm{yr}$, comparable with similar rates for a bog at Holdens Bay, Rotorua (McGlone 1983) and peat lakes in ine lowland Waikato region (Lowe 1988b; Newnham et al. 1989) (see also Froggatt \& Rogers 1990), but considerably slower than mean rates of c. $1 \mathrm{~mm} / \mathrm{yr}$ at Rukuhia and kopouatai Bogs in the Waikato region (Green \& Lowe 1985; Newnham et al. 1995b) and at Lake Poukawa, Hawke's Bay (Howorth et al. 1980). However, the rates of accumulation at Kaipo have varied with three distinct phases evident (Fig. 3): relatively slow $(0.17 \mathrm{~mm} / \mathrm{yr})$ before c. $12000{ }^{14} \mathrm{C}$ Ir BP (marked by Waiohau Tephra); relatively fast $(0.52 \mathrm{~mm} /$ r) from c. 12000 to $8500{ }^{14} \mathrm{C}$ yr BP; and very slow (0.07 mm/yr) after $8500{ }^{14} \mathrm{C} \mathrm{yr} \mathrm{BP} \mathrm{(marked} \mathrm{by} \mathrm{Rotoma}$ Tephra). (Rates in calendar years are c. $0.12,0.42$, and 0.06 $\mathrm{mm} / \mathrm{cal}$ yr, respectively.) This pattern may relate broadly to climatic change (cf. McGlone \& Topping 1977; Green \& l.owe 1985; Hogg et al. 1987). Newnham \& Lowe (in press) suggested that the general "tripartite" sequence at Kaipo, comprising lower and upper peat deposits with interrening brownish-grey muds, and the associated variations in sedimentation rates, resemble many "classic" sedimentary sequences from the North Atlantic margins where Younger Dryas cooling (between c. 11000 and $10000{ }^{14} \mathrm{C}$ yr BP) is best expressed (Björck et al. 1998; lijörck \& Wastegård 1999). Waiohau Tephra was identified by Newnham \& Lowe (in press) as an especially important chronostratigraphic datum in the sequence lecause it marks the base of the brownish-grey mud unit and the change in sedimentation rates that may represent a cooling signal.

\section{DISCUSSION AND CONCLUSIONS}

We have documented here the stratigraphic interrelationships, composition, and chronology of a succession of 16 distal, silicic tephra layers interbedded with peats and muds at the montane Kaipo Bog, Huiarau Range, eastern North Island. The base of the sediments is dated at c. $15000{ }^{14} \mathrm{C}$ yr BP (c. 18000 cal yr BP). Aged from $665 \pm 15$ to 14700 $\pm 95{ }^{14} \mathrm{C}$ yr BP, the tephras are derived from six different volcanic centres in North Island, three of which are rhyolitic (Okataina, Taupo, Maroa), one peralkaline (Tuhua), and two andesitic (Tongariro, Egmont). Correlations, based on multiple criteria, are necessarily provisional in some cases because of current ambiguities or limitations in relevant data.

Six of the tephras have not been recorded previously at the Kaipo site: Tuhua, Mamaku, Konini, Waiohau, Puketarata, and Rerewhakaaitu. Four of these (Tuhua. Mamaku, Konini, Puketarata) have not been recorded in eastern North Island, and so their occurrence at Kaipo Bog greatly extends their known distribution (Pullar \& Birrell 1973; Lowe 1988b; Froggatt \& Lowe 1990). It is likely that further microscopic or "cryptic" tephra layers (Hunt \& Lowe in prep.), not visible as macroscopic layers, will be present at Kaipo because such deposits have been recorded at Lake Tutira, c. $65 \mathrm{~km}$ to the south near Napier, and at Lake Repongaere, c. $60 \mathrm{~km}$ to the east near Gisborne (Fig. 1; Eden et al. 1993; Eden \& Froggatt 1996; Wilmshurst et al. 1999).

\section{Some important tephra markers}

The identification of Rerewhakaaitu Tephra at Kaipo Bog. and confirmation of its age at $14700 \pm 95^{14} \mathrm{C} \mathrm{yr} \mathrm{BP}$, provides further scope for its application as a critical marker bed at the end of the last cold stage in both terrestrial and marine environments (e.g., Stewart \& Neall 1984; Newnham et al. 1989; Carter et al. 1995).

The tephra identified at Kaipo as Puketarata Tephra and dated at c. $13100{ }^{14} \mathrm{C} \mathrm{yr} \mathrm{BP}$ is identical in composition to a Maroa-derived distal micro-tephra in the Waikato region dated at c. $14000{ }^{14} \mathrm{C}$ yr BP (Lowe 1988b). These deposits may be correlatives (in which case the Waikato estimated age is apparently too old) or they may be separate tephras erupted c. $1000{ }^{14} \mathrm{C}$ years apart but with a common source, presumably from vents in the Puketarata craters area (Brooker et al. 1993). In any event, the occurrence of the distinctive c. $13100{ }^{14} \mathrm{C}$ yr BP tephra at Kaipo is noteworthy because it is well beyond previously mapped limits (Lloyd 1972; Brooker et al. 1993) and it is potentially a useful chronostratigraphic marker bed.

Waiohau Tephra (11850 $\pm 60{ }^{14} \mathrm{C}$ yr BP) provides a critical chronostratigraphic marker at Kaipo, analagous to widespread tephras of similar age elsewhere that are used to correlate and date signals of lateglacial climatic change. Such tephras include the Laacher See, Vedde, Borrobol, and Ravel in northwest Europe (e.g., Bogaard \& Schminke 1985: Juvigné et al. 1992; Turney et al. 1997; Bauer et al. 1999; Björck \& Wastegård 1999), Glacier Peak tephra in North America (e.g., Busacca et al. 1992), the "Volcan Réclus" tephra in South America (McCulloch \& Bentley 1998), and the Towada-H and Ulreung Oki tephras in and around Japan (Machida 1999). 
The Egmont-derived Konini Tephra, now well dated at $10150 \pm 50{ }^{14} \mathrm{C}$ yr BP and identified in Taranaki, Waikato, and eastern North Island regions, forms a widespread marker bed for lateglacial-early Holocene conditions.

If our provisonal correlations are confirmed, then the occurrence of the Mt Ruapehu derived, c. $10100{ }^{14} \mathrm{C}$ yr BP Okupata Member of Taurewa Formation at well-separated sites in eastern North Island and the Waikato region is consistent with deposition from a substantial plinian eruption. This supports the conclusions of Donoghue et al. (1999) who showed the Taurewa Eruptive Episode to be the largest known from Mt Ruapehu since c. $22600{ }^{14} \mathrm{C}$ yr BP. The Okupata Member has an estimated total volume of at least $0.23 \mathrm{~km}^{3}$ (Donoghue et al. 1999).

Tuhua Tephra $\left(6130 \pm 30{ }^{14} \mathrm{C}\right.$ yr BP $)$, previously identified in the Auckland and Waikato regions northwest and southwest, respectively, of the source volcano at Mayor Island (Fig. 1; Lowe 1988b; Newnham \& Lowe 1991), was clearly distributed in a southeasterly direction as well (see also Kennedy \& Froggatt 1984). With its distinctive composition, Tuhua Tephra forms an important regional marker of mid-Holocene age (Newnham et al. 1995b).

The Taupo $\left(1850 \pm 10{ }^{14} \mathrm{C}\right.$ yr BP) and Kaharoa $(665 \pm$ $15{ }^{14} \mathrm{C}$ yr BP) Tephras, both identified at Kaipo Bog, are well established late Holocene marker beds in North Island. Kaharoa Tephra is essentially coincident with the earliest environmental impacts of Polynesian settlement (Lowe et al. 1998, in press; Newnham et al. 1998b; Wilmshurst et al. 1999).

\section{Glass composition}

The new major element compositional analyses on glass shards from each of the tephra layers, obtained by electron microprobe (Table 2), are valuable additions to the glass geochemical database being developed for New Zealand tephra layers, and thereby add to their potential usefulness as isochronous stratigraphic markers. Such analyses, especially those on the tephras from non-rhyolitic sources, which are sparse, are usually the most useful means of matching tephra layers to source volcanoes and, in many cases, to specific named eruptives (e.g., Froggatt 1983; Stokes et al. 1992; Dugmore et al. 1995; Pilcher et al. 1996; Shane et al. 1996; Cronin et al. 1997; Turney et al. 1997; Lowe \& Newnham 1999; Shane in press).

\section{Paleoenvironmental applications}

Establishing a sound chronology for the Kaipo peat sequence is an essential first step towards undertaking detailed, fineresolution paleoenvironmental studies at this climatically sensitive site (Newnham \& Lowe in press, in prep.). Ultimately, the chrono-tephrostratigraphy reported here will underpin attempts to correlate short-term regional or global paleoclimatic changes for the lateglacial and Holocene periods, and especially to determine the degree of synchrony of such changes between Northern and Southern Hemispheres, including the Younger Dryas chron (e.g., Lowell et al. 1995; Björck et al. 1996; Newnham \& Lowe in prep.). The chronostratigraphic framework that we have established for the Kaipo sequence is based on 34 reliable ages comprising 20 site-specific radiocarbon ages together with 14 mean ages on the tephra layers, which were derived from other North Island sites using tephrochronology. The sitespecific radiocarbon ages and the independently derived tephra-based ages show close accordance, indicating tha the sequence is soundly dated.

\section{ACKNOWLEDGMENTS}

We are grateful to Teresa Giles, Roland Gehrals, Alan Hogg Jonathan Palmer, and Limin Xiong, and the Department o Conservation (East Coast Hawke's Bay Conservancy) fo assistance in the field. Dave Manning is thanked for obtaining th electron microprobe analyses. We also appreciate receiving helpit advice and comment from Sue Donoghue, Phil Shane and Bren Alloway (tephra correlation), Tom Higham, Alan Hogg, and Bruc McFadgen (radiocarbon dating), Paul Froggatt and two othe (anonymous) reviewers, and Chris Hendy and Wim Rijske. DII is especially grateful to Mark Blacksell, Department o Geographical Sciences, University of Plymouth, for access t facilities during study leave in 1998. The study was funded in pat by a British Council (Wellington, New Zealand) "Higher Educatio Link" travel grant between Waikato and Plymouth universitiz: and by a grant (AP59454) from the New Zealand Lottery Grant Board for Science.

\section{REFERENCES}

Alloway, B. V.; Lowe, D. J.; Chan, R. P. K.; Eden, D. N.; Froggat P. C. 1994: Stratigraphy and chronology of the Stent teph a c. 4000 year old distal silicic tephra from Taupo Volcani Centre, New Zealand. New Zealand Journal of Geolog and Geophysics 37: 37-47.

Alloway, B. V.; Neall, V. E.; Vucetich, C. G. 1995: Late Quaternar (post 28,000 year B.P.) tephrostratigraphy of northeast an central Taranaki, New Zealand. Journal of the Royc Society of New Zealand 25: 385-458.

Ammann, B.; Lotter, A. F. 1989: Late-glacial radiocarbon an palynostratigraphy on the Swiss Plateau. Boreas is 109-126.

Bauer, A.; Endres, C.; Günter, C.; Litt, T.; Stebich, M.; Negendanl J. F. W. 1999: High resolution sediment and vegetatio responses to Younger Dryas climate change in varved $\mathrm{l} k \mathrm{k}$ sediments from Meerfelder Maar, Germany. Quaternur Science Reviews 18: 321-329.

Björck, J.; Wastegård, S. 1999: Climate oscillations an tephrochronology in eastern middle Sweden during the 1 : glacial-interglacial transition. Journal of Quaterncir Science 14: 399-410.

Björck, S.; Kromer, B.; Johnsen, S.; Bennike, O.; Hammarlunı D.; Lemdahl, G.; Possnert, G.; Rasmussen, T. I Wohlfarth, B.; Hammer, C. U.; Spurk, M. $195 \mathrm{t}$ Synchronized terrestrial-atmospheric deglacial recorc around the North Atlantic. Science 274: 1155-1160.

Björck, S.; Walker, M. J. C.; Cwynar, L. C.; Johnsen, S.; Knudsel K.; Lowe, J. J.; Wohlfarth, B.; INTIMATE Members 1998 An event stratigraphy for the Last Termination in the Not Atlantic region based on the Greenland ice-core record: proposal by the INTIMATE group. Journal of Quaternit Science 13: 283-292.

Bogaard, P. v d; Schminke, H. -U. 1985: Laacher See Tephra: widespread isochronous late Quaternary tephra layer $\mathrm{i}$ central and northern Europe. Geological Society of Americ Bulletin 96: 1554-1571.

Bond, G.; Showers, W.; Cheseby, M.; Lotti, R.; Almasi, P Demenocal, P.; Priore, P.; Cullen, H.; Hajdas, I.; Bonan G. 1997: A pervasive millennial-scale cycle in Not Atlantic Holocene and glacial climates. Science 27 1257-1266.

Bronk Ramsey, C. 1995: Radiocarbon calibration and analysis , stratigraphy: the OxCal program. Radiocarbon 3 : 425-430. 
Brooker, M. R.; Houghton, B. F.; Wilson, C. J. N.; Gamble, J. A. 1993: Pyroclastic phases of a rhyolitic dome-building eruption: Puketarata tuff ring, Taupo Volcanic Zone, New Zealand. Bulletin of Volcanology 55: 395-406.

Busacca, A. J.; Nelstead, K. T.; McDonald, E. V.; Purser, M. D. 1992: Correlation of distal tephra layers in loess in the channeled scabland and palouse of Washington State. Quaternary Research 37: 281-232.

Carter, L.; Nelson, C. S.; Neil, H. L.; Froggatt, P. C. 1995: Correlation, dispersal, and preservation of the Kawakawa Tephra and other late Quaternary tephra layers in the Southwest Pacific Ocean. New Zealand Journal of Geology and Geophysics 38: 29-46.

Cronin, S. J.; Neall, V. E.; Stewart, R. B.; Palmer, A. S. 1996: A multiple-parameter approach to andesitic tephra correlation, Ruapehu volcano, New Zealand. Journal of Volcanology and Geothermal Research 72: 199-215.

Cronin, S. J.; Neall, V. E.; Palmer, A. S.; Stewart, R. B. 1997: Methods of identifying late Quaternary rhyolitic tephras on the ring plains of Ruapehu and Tongariro volcanoes, New Zealand. New Zealand Journal of Geology and Geophysics 40: 175-184.

Dansgaard, W.; Johnsen, S. J.; Clausen, H. B.; Dahl-Jensen, D.; Gundestrup, N. S.; Hammer, C. U.; Hvidberg, C. S.; Steffensen, J. P.; Sveinbjörnsdottir, A. E.; Jouzel, J.; Bond, G. 1993: Evidence for general instability of past climate from a 250-kyr ice-core record. Nature 364: 218-220.

Denton, G. H.; Hendy, C. H. 1994: Younger Dryas age advance of the Franz Josef glacier in the Southern Alps of New Zealand. Science 264: 1434-1437.

I onoghue, S. L.; Neall, V. E. 1996: Tephrostratigraphic studies at Tongariro Volcanic Centre, New Zealand: an overview. Quaternary International 34-36: 13-20.

I Oonoghue, S. L.; Stewart, R. B.; Palmer, A. S. 1991: Morphology and chemistry of olivine phenocrysts of Mangamate Tephra, Tongariro Volcanic Centre, New Zealand. Journal of the Royal Society of New Zealand 21:225-236.

Donoghue, S. L.; Gamble, J. A.; Palmer, A. S.; Stewart, R. B. 1995a: Magma mingling in an andesitic pyroclastic flow of the Pourahu Member, Ruapehu volcano, New Zealand Journal of Volcanology and Geothermal Research 68: $177-191$.

Donoghue, S. L.; Neall, V. E.; Palmer, A. S. 1995b: Stratigraphy and chronology of late Quaternary andesitic tephra deposits, Tongariro Volcanic Centre, New Zealand. Journal of the Royal Society of New Zealand 25: 115-206

Ionoghue, S. L.; Neall, V. E.; Palmer, A. S.; Stewart, R. B. 1997: The volcanic history of Ruapehu during the past 2 millennia based on the record of Tufa Trig tephras. Bulletin of Volcanology 59: 136-146.

Donoghue, S. L.; Palmer, A. S.; McClelland, E.; Hobson, K; Stewart, R. B.; Neall, V. E.; Lecointre, J.; Price, R. C. 1999: The Taurewa Eruptive Episode: evidence for climactic eruptions at Ruapehu volcano, New Zealand. Bulletin of Volcanology 60: 223-340.

I) ugmore, A. J.; Larsen, G.; Newton, A. J. 1995: Seven tephra isochrones in Scotland. The Holocene 5: 257-266.

İden, D. N.; Froggatt, P. C. 1996: A 6500-year-old history of tephra deposition recorded in the sediments of Lake Tutira, eastern North Island, New Zealand. Quaternary Internationa! 3436: 55-64.

İden, D. N.; Froggatt, P. C.; Trustrum, N. A.; Page, M. J. 1993: A multiple-source Holocene tephra sequence from Lake Tutira, Hawke's Bay, New Zealand. New Zealand Journal of Geology and Geophysics 36: 233-242.
Ewart, A.; Taylor, S. R.; Capp, A. C. 1968: Trace and minor element geochemistry of rhyolitic volcanic rocks, central North Island, New Zealand-total rock and residual liquid data. Contributions to Mineralogy and Petrology 18: 76-104.

Froggatt, P. C. 1983: Toward a comprehensive Upper Quaternary tephra and ignimbrite stratigraphy in New Zealand using electron microprobe analysis of glass shards. Quaternary Research 19: 188-200.

Froggatt, P. C.; Lowe, D. J. 1990: A review of late Quaternary silicic and some other tephra formations from New Zealand: their stratigraphy, nomenclature, distribution, volume, and age. New Zealand Journal of Geology and Geophysics 33: 89-109.

Froggatt, P. C.; Rogers, G. M. 1990: Tephrostratigraphy of high altitude peat bogs along the axial ranges, North Island, New Zealand. New Zealand Journal of Geology and Geophysics 33: $111-124$.

Giles, T. M.; Newnham, R. M.; Lowe, D. J.; Munro, A. J. 1999: Impact of tephra fall and environmental change: a 1000 year record from Matakana Island, Bay of Plenty, North Island, New Zealand. In: Firth, C.; McGuire, W. J. ed. Volcanoes in the Quaternary. The Geological Society. London, Special Publications 161: 11-26.

Green, J. D.; Lowe, D. J. 1985: Stratigraphy and development of c. 17000 year old Lake Maratoto, North Island, New Zealand, with some inferences about postglacial climatic change. New Zealand Journal of Geology and Geophysics 28: 675-699.

Hogg, A. G.; McCraw, J. D. 1983: Late Quaternary tephras of Coromandel Peninsula, North Island, New Zealand: a mixed peralkaline and calkalkaline tephra sequence. New Zealand Journal of Geology and Geophysics 26: 163-187.

Hogg, A. G.; Lowe, D. J.; Hendy, C. H. 1987: University of Waikato radiocarbon dates I. Radiocarbon 29: 263-301

Holdaway, R. N.; Beavan, N. R. 1999: Reliable ${ }^{14}$ C AMS dates on bird and Pacific rat Rattus exulans bone gelatin, from a $\mathrm{CaCO}_{3}$-rich deposit. Journal of the Royal Society of New Zealand 29: 185-211.

Houghton, B. F.; Wilson, C. J. N.; McWilliams, M. O.; Lanphere, M. A.; Weaver, S. D.; Briggs, R. M.; Pringle, M. S. 1995 Chronology and dynamics of a large silicic magmatic system: central Taupo Volcanic Zone, New Zealand. Geology 23: 13-16.

Howorth, R.; Froggatt, P. C.; Robertson, S. M. 1980: Late Quaternary volcanic ash stratigraphy of the Poukawa area central Hawke's Bay, New Zealand. New Zealand Journal of Geology and Geophysics 23: 487-491.

Hunt, J. B.; Lowe, D. J. in prep.: Tephra nomenclatura. Journal of Archaeological Science.

Juvigné, E. T.; Kroonenberg, S. B.; Veldkamp, A.; El Arabi, A.; Vernet, G. 1992: Widespread Allerød and Boreal trachyandesitic to trachytic tephra layers as stratigraphical markers in the Massif Central, France. Quaternaire 3: $137-146$.

Kennedy, N. M.; Froggatt, P. C. 1984: Recognition of Tuhua Tephra (c. 6,200 BP) at Rotorua. Geological Society of New Zealand Newsletter 66: 17-18.

Kohn, B. P.; Neall, V. E. 1973: Identification of late Quaternary tephras for dating Taranaki lahar deposits. New Zealand Journal of Geology and Geophysics 16: 781-792.

Le Bas, M. J.; Le Maitre, R. W.; Streckeisen, A.; Zanettin, B. 1986: A chemical classification of volcanic rocks based on the total alkali-silica diagram. Journal of Petrology 27: $745-750$

Lloyd, E. F. 1972: Geology and hot springs of Orakeikorako. New Zealand Geological Survey Bulletin 85. 
Lowe, D. J. 1986: Revision of the age and stratigraphic relationships of Hinemaiaia Tephra and Whakatane Ash, North Island, New Zealand, using distal occurrences in organic deposits. New Zealand Journal of Geology and Geophysics 29: 61-73.

Lowe, D. J. 1988a: Late Quaternary volcanism in New Zealand: towards an integrated record using distal airfall tephras in lakes and bogs. Journal of Quaternary Science 3: 111-120.

Lowe, D. J. 1988b: Stratigraphy, age, composition, and correlation of late Quaternary tephras interbedded with organic sediments in Waikato lakes, North Island, New Zealand. New Zealand Journal of Geology and Geophysics 31: 125-165.

Lowe, D. J.; de Lange, W. P. in press: Volcano-meteorological tsunamis, the c. AD 200 Taupo eruption (New Zealand) and the possibility of a global tsunami. The Holocene 10.

Lowe, D. J.; Hogg, A. G. 1986: Tephrostratigraphy and chronology of the Kaipo Lagoon, an 11,500 year-old montane peat bog in Urewera National Park, New Zealand. Journal of the Royal Society of New Zealand 16: 25-41.

Lowe, D. J.; Newnham, R. M. 1999: Advances in Quaternary tephrostratigraphy and tephrochronology in New Zealand. Quaternary Australasia 17: 12-19.

Lowe, D. J.; Green, J. D.; Northcote, T. G.; Hall, K. J. 1997: Holocene fluctuations of a meromictic lake in southern British Columbia. Quaternary Research 48: 100-113.

Lowe, D. J.; McFadgen, B. G.; Higham, T. F. G.; Hogg, A. G.; Froggatt, P. C.; Nairn, I. A. 1998: Radiocarbon age of the Kaharoa Tephra, a key marker for late-Holocene stratigraphy and archaeology in New Zealand. The Holocene 8: 487-495.

Lowe, D. J.; Newnham, R. M.; McFadgen, B. G.; Higham, T. F. G. in press: Tephras and New Zealand archaeology. Journal of Archaeological Science.

Lowe, J. J.; Walker, M. J. C. 1997: Reconstructing Quaternary environments. $2^{\text {nd }}$ ed. London, Longman. $446 \mathrm{p}$.

Lowell, T. V.; Heusser, C. J.; Anderson, B. G.; Moreno, P. I.; Hauser, A.; Heusser, L. E.; Schlüchter, C.; Marchant, D. R.; Denton, G. H. 1995: Interhemispheric correlation of late Pleistocene glacial events. Science 269: 1541-1549.

McCormac, F. G.; Hogg, A. G.; Higham, T. F. G.; Baillie, M. G. L.; Palmer, J. G.; Xiong, L.; Pilcher, J. R.; Brown, D.; Hoper, S. T. 1998: Variations of radiocarbon in tree rings: Southern Hemisphere offset preliminary results. Radiocarbon 40: 1153-1159.

McCulloch, R. D.; Bentley, M. J. 1998: Late glacial ice advances in the Strait of Magellan, southern Chile. Quaternary Science Reviews 17: 775-787.

McGlone, M. S. 1983: Holocene pollen diagrams, Lake Rotorua, North Island, New Zealand. Journal of the Royal Society of New Zealand 13: 53-65.

McGlone, M. S. 1995: Lateglacial landscape and vegetation change and the Younger Dryas climate oscillation in New Zealand. Quaternary Science Reviews 14: 867-881.

McGlone, M. S.; Topping, W. W. 1977: Aranuian (post-glacial) pollen diagrams from the Tongariro region, North Island, New Zealand. New Zealand Journal of Botany 15: 749-760.

McKelvey, P. J. 1973: The pattern of the Urewera forests. New Zealand Forest Research Institute Technical Paper 59: $1-48$.

Machida, H. 1999: The stratigraphy, chronology and distribution of distal marker-tephras in and around Japan. Global and Planetary Change 21: 71-94.

Manning, D. A. 1995: Late Pleistocene tephrostratigraphy of the eastern Bay of Plenty, North Island, New Zealand. Unpublished $\mathrm{PhD}$ thesis, lodged in the Library, Victoria University of Wellington, Wellington, New Zealand.
Moore, P. R. 1979: Rock types and surface deposits: Urewerla Waikaremoana, 1:100,000. NZMS 290 W $17 / 18$ Wellington, New Zealand. Department of Scientific an Industrial Research.

Nairn, I. A.; Kobayashi, T.; Nakagawa, M. 1998: The $\sim 10 \mathrm{k}$ multiple vent pyroclastic eruption sequence at Tongar $\mathrm{r}$ Volcanic Centre, Taupo Volcanic Zone, New Zealand: $P$ al 1. Eruptive processes during regional extension. Jourr'c of Volcanology and Geothermal Research 86: 19-44.

Nakagawa, M.; Nairn, I. A.; Kobayashi, T. 1998: The $\sim 10 \mathrm{k}$ multiple vent pyroclastic eruption sequence at Tongar $r$ Volcanic Centre, Taupo Volcanic Zone, New Zealand: P x 2. Petrological insights into magma storage and transp $m$ during regional extension. Journal of Volcanology an Geothermal Research 86: 45--65.

Newnham, R. M.; Lowe, D. J. 1991: Holocene vegetation an volcanic activity, Auckland Isthmus, New Zealand. Journc of Quaternary Science 6: 177-193.

Newnham, R. M.; Lowe, D. J. in press: The search for the Young, Dryas in New Zealand using tephrochronolos? Quaternaire.

Newnham, R. M.; Lowe, D. J. in prep.: A fine-resolution recor of late-glacial climate reversal from New Zealand. Geolog (submitted).

Newnham, R. M.; Lowe, D. J.; Green, J. D. 1989: Palynolons vegetation and climate of the Waikato lowlands, Not Island, New Zealand, since c. 18000 years ago. Jourr c of the Royal Society of New Zealand 19: 127-150.

Newnham, R. M.; Lowe, D. J.; Wigley, G. N. A. 1995a: Lيt Holocene palynology and palaeovegetation of tephra bearing mires at Papamoa and Waihi Beach, western Ba of Plenty, North Island, New Zealand. Journal of the Roy' Society of New Zealand 25: 283-300.

Newnham, R. M.; de Lange, P. J.; Lowe, D. J. 1995b: Holocen vegetation, climate, and history of a raised bog compls? northern New Zealand, based on palynology, plar macrofossils and tephrochronology. The Holocent' 267-282.

Newnham, R. M.; Lowe, D. J.; Matthews, B. W. 1998a: A la:t Holocene and prehistoric record of environmental chang from Lake Waikaremoana, New Zealand. The Holoce'n 8: $443-454$.

Newnham, R. M.; Lowe, D. J.; McGlone, M. S.; Wilmshurst, J. M Higham, T. F. G. 1998b: The Kaharoa Tephra as a critice datum for earliest human impacts in northern New Zealanic Journal of Archaeological Science 25: 533-544.

New Zealand Forest Service 1969: Sheet 96-Maungapohaz Forest map of New Zealand 1:63,360. Type Map Series a

Pilcher, J. R.; Hall, V. A.; McCormac, F. G. 1996: An outlin tephrochronology for the Holocene of the north of Irelaric Journal of Quaternary Science 11: 485-494.

Pillans, B. J.; Wright, I. 1992: Late Quaternary tephrostratigraph from the southern Havre Trough-Bay of Plenty, northeas New Zealand. New Zealand Journal of Geology an Geophysics 35: 129-143.

Price, R. C.; Stewart, R. B.; Woodhead, J. D.; Smith, I. E. M. 19uc Petrogenesis of high-K arc magmas: evidence fror Egmont volcano, North Island, New Zealand. Journal c Petrology 40: 167-197.

Pullar, W. A.; Birrell, K. S. 1973: Age and distribution of lat Quaternary pyroclastic and associated cover deposits $\mathrm{C}$ the Rotorua and Taupo area, North Island, New Zealar. New Zealand Soil Survey Report 1.

Rijkse, W. C. 1979: Soils of part Urewera-Waikaremoana arec North Island, New Zealand. New Zealand Soil Surve. Report 45. 
Rogers, N. B. 1984: The vegetation and history of Kaipo and other natural peatland clearings, Urewera National Park, New Zealand. Unpublished MSc thesis, lodged in the Library, University of Waikato, Hamilton, New Zealand.

Seidenkrantz, M. -S.; Kristensen, P.; Knudsen, K. L. 1995: Marine evidence for climatic instability during the last interglacial in shelf records from northwest Europe. Journal of Quaternary Science 10: 77-82.

Shane, P. A. R. in press: Tephrochronology: a New Zealand case study. Earth-Science Reviews.

Shane, P. A. R.; Froggatt, P. C. 1994: Discriminant function analysis of glass chemistry of New Zealand and North American tephra deposits. Quaternary Research 41: 70-81.

Shane, P. A. R.; Black, T. M.; Alloway, B. V.; Westgate, J. A. 1996: Early to Middle Pleistocene tephrochronology of North Island, New Zealand: implications for volcanism, tectonism and palaeoenvironments. Geological Society of America Bulletin 108: 915-925.

Sparks, R. J.; Melhuish, W. H.; McKee, J. W. A.; Ogden, J.; Palmer, J. G. 1995: ${ }^{14} \mathrm{C}$ calibration in the Southern Hemisphere and the date of the last Taupo eruption: evidence from treering sequences. Radiocarbon 37: 155-163.

Stewart, R. B.; Neall, V. E. 1984: Chronology of palaeoclimatic change at the end of the last glaciation. Nature 311: 47-48.

Stokes, S.; Lowe, D. J. 1988: Discriminant function analysis of late Quaternary tephras from five volcanoes in New Zealand using glass shard major element chemistry. Quaternary Research 30: 270-283.

Stokes, S.; Lowe, D. J.; Froggatt, P. C. 1992: Discriminant function analysis and correlation of late Quaternary rhyolitic tephra deposits from Taupo and Okataina volcanoes, New Zealand, using glass shard major element composition. Quaternary International 13-14: 103-117.

Stuiver, M.; van der Plicht, J. ed. 1998: INTCAL98: calibration issue. Radiocarbon 40 (3): i-xiv, 1041-1164.

Stuiver, M.; Reimer, P. J.; Bard, E.; Beck, J. W.; Burr, G. S.; Hughen, K. A.; Kromer, B.; McCormac, G.; van der Plicht, J.; Spurk, M. 1998: INTCAL98 radiocarbon age calibration, 24,000-0 cal BP. Radiocarbon 40: 1041-1083.

Taylor, K. C.; Mayewski, P. A.; Alley, R. B.; Brook, E. J.; Gow, A. J.; Grootes, P. M.; Meese, D. A.; Saltzman, B.; Severinghaus, J. P.; Twickler, M. S.; White, J. W. C.; Whitlow, S.; Zielinski, G. A. 1997: The Holocene-Younger Dryas transition recorded at Summit, Greenland. Science 278: 825-827.
Topping, W. W. 1973: Tephrostratigraphy and chronology of late Quaternary eruptives from the Tongariro Volcanic Centre New Zealand. New Zealand Journal of Geology anc Geophysics 16: 397-423.

Topping, W. W.; Kohn, B. P. 1973: Rhyolitic tephra marker beds in the Tongariro area, North Island, New Zealand. Neu Zealand Journal of Geology and Geophysics 16 : 375-395.

Turney, C. S. M.; Harkness, D. D.; Lowe, J. J. 1997: The use of microtephra horizons to correlate Late-glacial lake sediment successions in Scotland. Journal of Quaternar Science 12: 525-531.

Vucetich, C. G.; Pullar, W. A. 1973: Holocene tephra formations erupted in the Taupo area, and interbedded tephras from other sources. New Zealand Journal of Geology ana Geophysics 16: 745-780.

Ward, C. M. 1995: The Lake Waikareiti landslide, Te Urewera National Park. Geological Society of New Zealana Miscellaneous Publication 81A: 184.

Wilmshurst, J, M.; McGlone, M. S. 1996: Forest disturbance in the central North Island, New Zealand, following the 1850 BP Taupo eruption. The Holocene 6: 399-411.

Wilmshurst, J. M.; Eden, D. N.; Froggatt, P. C. 1999: Late Holocene forest disturbance in Gisborne, New Zealand: a comparison of terrestrial and marine pollen records. New Zealand Journal of Botany 37: 528-540.

Wilson, C. J. N. 1993: Stratigraphy, chronology, styles and dynamics of late Quaternary eruptions from Taupo volcano, New Zealand. Philosophical Transactions of the Royal Society London A343: 205-306.

Wilson, C. J. N.; Ambraseys, N. N.; Bradley, J.; Walker, G. P. L. 1980: A new date for the Taupo eruption. Nature 288: 252-253.

Yoshikawa, T.; Ikeda, Y.; Iso, N.; Moriya, I.; Hull, A. G.; Ota, Y. 1988: Origin and age of erosion surfaces in the upper drainage basin of Waiapu River, northeastern North Island, New Zealand. New Zealand Journal of Geology and Geophysics 31: 101-109.

Zielinski, G. A.; Mayewski, P. A.; Meeker, L. D.; Whitlow, S.; Twickler, M. S.; Morrison, M.; Meese, D. A.; Gow, A. J.; Alley, R. B. 1994: Record of volcanism since 7000 B.C. from the GISP2 Greenland ice core and implications for the volcano-climate system. Science 264: 948-952. 